\title{
LONG-TERM $\mathrm{CO}_{2}$ ENRICHMENT OF A FOREST ECOSYSTEM: IMPLICATIONS FOR FOREST REGENERATION AND SUCCESSION
}

\author{
Jacqueline E. Mohan, ${ }^{1,2,3,5}$ James S. Clark, ${ }^{1,4}$ and William H. Schlesinger ${ }^{1,4}$ \\ ${ }^{1}$ Duke University, Graduate Program in Ecology, and Department of Biology, Durham, North Carolina 27708 USA \\ ${ }^{2}$ Harvard University, Department of Organismic and Evolutionary Biology, Cambridge, Massachusetts 02138 USA \\ ${ }^{3}$ The Ecosystem Center, Marine Biological Laboratory, Woods Hole, Massachusetts 02543 USA \\ ${ }^{4}$ Nicholas School of the Environment and Earth Sciences, Duke University, Durham, North Carolina 27708 USA
}

Abstract. The composition and successional status of a forest affect carbon storage and net ecosystem productivity, yet it remains unclear whether elevated atmospheric carbon dioxide $\left(\mathrm{CO}_{2}\right)$ will impact rates and trajectories of forest succession. We examined how $\mathrm{CO}_{2}$ enrichment $(+200 \mu \mathrm{L} \mathrm{CO} / / \mathrm{L}$ air differential) affects forest succession through growth and survivorship of tree seedlings, as part of the Duke Forest free-air $\mathrm{CO}_{2}$ enrichment (FACE) experiment in North Carolina, USA. We planted 2352 seedlings of 14 species in the low light forest understory and determined effects of elevated $\mathrm{CO}_{2}$ on individual plant growth, survival, and total sample biomass accumulation, an integrator of plant growth and survivorship over time, for six years. We used a hierarchical Bayes framework to accommodate the uncertainty associated with the availability of light and the variability in growth among individual plants.

We found that most species did not exhibit strong responses to $\mathrm{CO}_{2}$. Ulmus alata $(+21 \%)$, Quercus alba $(+9.5 \%)$, and nitrogen-fixing Robinia pseudoacacia $(+230 \%)$ exhibited greater mean annual relative growth rates under elevated $\mathrm{CO}_{2}$ than under ambient conditions. The effects of $\mathrm{CO}_{2}$ were small relative to variability within populations; however, some species grew better under low light conditions when exposed to elevated $\mathrm{CO}_{2}$ than they did under ambient conditions. These species include shade-intolerant Liriodendron tulipifera and Liquidambar styraciflua, intermediate-tolerant Quercus velutina, and shade-tolerant Acer barbatum, A. rubrum, Prunus serotina, Ulmus alata, and Cercis canadensis. Contrary to our expectation, shade-intolerant trees did not survive better with $\mathrm{CO}_{2}$ enrichment, and populationscale responses to $\mathrm{CO}_{2}$ were influenced by survival probabilities in low light. $\mathrm{CO}_{2}$ enrichment did not increase rates of sample biomass accumulation for most species, but it did stimulate biomass growth of shade-tolerant taxa, particularly Acer barbatum and Ulmus alata. Our data suggest a small $\mathrm{CO}_{2}$ fertilization effect on tree productivity, and the possibility of reduced carbon accumulation rates relative to today's forests due to changes in species composition.

Key words: Bayesian analysis; carbon dioxide $\left(\mathrm{CO}_{2}\right)$ enrichment; forest succession; global change; hierarchical Bayes.

\section{INTRODUCTION}

Understanding how successional forests respond to rising atmospheric carbon dioxide $\left(\mathrm{CO}_{2}\right)$ concentrations is critical for predicting future forest composition, diversity, and productivity. Owing to fossil fuel emissions and tropical deforestation, the current concentration of $\sim 380 \mu \mathrm{L} / \mathrm{L}\left(\mathrm{CO}_{2} /\right.$ air $)$ is expected to increase to $580 \mu \mathrm{L} / \mathrm{L}$ by the middle of this century (Prentice et al. 2001), representing the highest $\mathrm{CO}_{2}$ level in the past $15 \times$ $10^{6}$ years (Petit et al. 1999, Pearson and Palmer 2000). Concurrently, the proportion of the globe supporting successional ecosystems is increasing due to human land use and disturbance (Bazzaz 1996, Vitousek et al. 1997, Imhoff et al. 2004). Forests dominated by productive,

Manuscript received 27 October 2005; revised 25 April 2006; accepted 3 May 2006. Corresponding Editor: B. A. Hungate.

${ }_{5}^{5}$ Present address: Harvard University, Harvard Forest, 324 North Main Street, Petersham, Massachusetts 01366 USA. E-mail: jmohan@mbl.edu early successional trees are typically net carbon sinks (Goulden et al. 1996, Barford et al. 2001, Deckmyn et al. 2004, Finzi et al. 2004). Such forests exhibit maximum rates of net ecosystem productivity (NEP), representing sequestered carbon (Peet 1992, Ryan et al. 1997, 2004, Schlesinger 1997, Caspersen et al. 2000, Wardle et al. 2004). Forests of the eastern United States in particular are accumulating biomass as they recover from 19th and 20th century land clearance (Delcourt and Harris 1980, Dixon et al. 1994, Hurtt et al. 2002, Foster et al. 2004), and carbon sequestration by such forests is an important component of the global carbon cycle (Ciais et al. 1995, Caspersen et al. 2000, Pacala et al. 2001, Houghton 2003, Beedlow et al. 2004, Cao et al. 2004). Although its impacts on forests are unknown, elevated $\mathrm{CO}_{2}$ accelerated successional change toward dominance by later successional taxa in a grassland community (Polley et al. 2003). Projected feedbacks to the global carbon budget may differ if elevated $\mathrm{CO}_{2}$ preferentially benefits early or late successional tree species, potentially impacting 
demographic patterns, probabilities of attaining canopy dominance, and future NEP levels.

The literature is equivocal regarding the relative success of successional functional groups under elevated $\mathrm{CO}_{2}$. In glasshouse and chamber studies, high $\mathrm{CO}_{2}$ has been observed to benefit both early (Brown and Higginbotham 1986, Hättenschwiler and Körner 1996, Hoddinott and Scott 1996) and late (Bazzaz and Miao 1993, Kubiske and Pregitzer 1996, 1997, Kinney and Lindroth 1997, Hättenschwiler and Körner 2000, Kerstiens 2001, Khurana and Singh 2004) successional forest species. Early-successional, shade-intolerant plants often have increased quantum yields and decreased light compensation points (the light level at which plants have zero net carbon assimilation and growth, and below which negative growth rates ultimately lead to death) when grown under high $\mathrm{CO}_{2}$ conditions (Ehleringer and Björkman 1977, Chen et al. 1999), and have spread into shadier experimental microsites when given supplemental $\mathrm{CO}_{2}$ (Hättenschwiler and Körner 1996). Early successional species are typically faster growing than late successional species (Bazzaz and Pickett 1980, Pacala et al. 1996), and species with intrinsically high growth rates under ambient $\mathrm{CO}_{2}$ conditions often obtain greater $\mathrm{CO}_{2}$ growth stimulation than slow-growing species (Poorter 1993, 1998, Ackerly and Bazzaz 1995). Elevated atmospheric $\mathrm{CO}_{2}$ is a potential cause of the recent increase in growth of intrinsically fast-growing Amazonian tree species (Laurance et al. 2004).

Other studies suggest that later successional, shadetolerant trees tend to preferentially benefit from $\mathrm{CO}_{2}$ enrichment (Bazzaz and Miao 1993, Kubiske and Pregitzer 1996, 1997, Hättenschwiler and Körner 2000, Kerstiens 2001). Model results of Lloyd and Farquhar (1996) predict slow-growing species preferentially benefit from elevated $\mathrm{CO}_{2}$. The overall importance of rising $\mathrm{CO}_{2}$ for enhancing temperate forest productivity has been questioned (Caspersen et al. 2000). The potential impact of elevated $\mathrm{CO}_{2}$ on forest regeneration and succession in the face of natural environmental variability remains unknown.

Different responses to elevated $\mathrm{CO}_{2}$ have been observed among species within the same functional group (Bazzaz and Miao 1993, Reid and Strain 1994, Hättenschwiler and Körner 1996, 2000, Hättenschwiler 2001, Bergh et al. 2003, Polley et al. 2003, Niklaus and Körner 2004) and even among groups and individuals of the same tree species (DeLucia et al. 1994, Wayne and Bazzaz 1997, Wang et al. 2000, Mohan et al. 2004). These disparate findings may result from unrealistic resource levels and community interactions that have not been adequately reproduced in artificial experimental settings (Ackerly and Bazzaz 1995), from individualistic species responses (Hättenschwiler and Körner 2000, Belote et al. 2004), or from genetic variation within a species (Wayne and Bazzaz 1997, Wang et al. 2000, Mohan et al. 2004). Thus studies using a limited number of trees growing under artificial conditions may be misleading. Clearly, studies are needed from intact forest understories, where $\mathrm{CO}_{2}$ can be manipulated (Field et al. 1992, Nowak et al. 2004). Such studies must allow for the full variability in resource levels (i.e., light and $\mathrm{CO}_{2}$ ) and in the populations that respond to them (Clark et al. 2003).

Here, we determine the impacts of elevated atmospheric $\mathrm{CO}_{2}$ on the growth and survivorship of individuals and on biomass accumulation rates of temperate tree species. We initiated experiments to test how functional groups, species, and individual trees respond to elevated $\mathrm{CO}_{2}$ in the Duke Forest free-air $\mathrm{CO}_{2}$ enrichment (FACE) facility in North Carolina, USA. $\mathrm{CO}_{2}$ fumigation of this intact forest provides an opportunity to examine $\mathrm{CO}_{2}$ effects on forest understory tree dynamics and successional processes in the face of natural environmental variability, including one hurricane (which occurred before the advent of the present study), several severe winter ice storms (particularly in 2002), and a long-term drought from 1998 to 2002. Secondary succession in Duke Forest is well-documented under ambient $\mathrm{CO}_{2}$ conditions (Oosting 1942, Keever 1950, Christensen and Peet 1981, 1984). Over 20 years in age, the experimental forest is entering the "thinning phase" during which competition for light and soil resources is intense (Christensen and Peet 1984, Peet 1992, Oren et al. 2001). Typical of forest understory environments (Canham et al. 1994, Kobe et al. 1995, Kobe and Coates 1997, Clark et al. 2003) the FACE understory is shady, with light availability in year 2000, as determined by hemispherical photography, averaging $2.8 \%$ full sunlight. Because elevated $\mathrm{CO}_{2}$ may affect the outcome of competition for non- $\mathrm{CO}_{2}$ resources (Bazzaz and McConnaughay 1992, Oren et al. 2001, Niklaus and Körner 2004, Nowak et al. 2004), this forest provides an ideal setting to assess potential $\mathrm{CO}_{2}$ impacts on temperate forest successional dynamics.

\section{Methods \\ Site description and design}

Forests now cover much of the southeastern United States on lands that were abandoned from agriculture early in the last century. In 1996, three ambient ( $\sim 365$ $\mu \mathrm{L} \mathrm{CO} 2 / \mathrm{L}$ air $)$ and three elevated $(+200 \mu \mathrm{L} / \mathrm{L}$ differential, for a concentration of $\sim 565 \mu \mathrm{L} \mathrm{CO} / \mathrm{L})$ plots, each $707 \mathrm{~m}^{2}$ in area, were established in a 13-yr-old unmanaged loblolly pine stand at the Duke Forest FACE site, one of the few facilities to test $\mathrm{CO}_{2}$ effects on an intact forest system (Hendrey et al. 1999). $\mathrm{CO}_{2}$ treatments commenced September 1996. With a range extending from Delaware to Texas, Pinus taeda L. (loblolly pine) is one of the most common tree species in the southeastern United States, particularly on the Piedmont and Coastal Plain physiographic provinces (Martin et al. 1993). It plays a prominent role in secondary succession on abandoned land, being among the first woody species to invade (Oosting 1942, Keever 
TABle 1. The 14 tree species planted in subplots at the Duke Forest FACE experiment.

\begin{tabular}{|c|c|c|c|c|}
\hline Species & Common name & Shade tolerance & No. trees per subplot & Total no. trees \\
\hline Acer barbatum & southern sugar maple & tolerant & 1 & $35 \dagger$ \\
\hline Acer rubrum & red maple & tolerant & 5 & 240 \\
\hline Cercis canadensis & eastern redbud & tolerant & 4 & 192 \\
\hline Liquidambar styraciflua & sweetgum & intolerant & 5 & 240 \\
\hline Liriodendron tulipifera & tulip poplar & intolerant & 4 & 192 \\
\hline Pinus echinata & shortleaf pine & intolerant & 3 & 144 \\
\hline Pinus taeda & loblolly pine & intolerant & 3 & 144 \\
\hline Prunus serotina & black cherry & tolerant & 3 & 144 \\
\hline Quercus alba & white oak & intermediate & 3 & 144 \\
\hline Quercus phellos & willow oak & intolerant & 3 & 144 \\
\hline Quercus rubra & red oak & intermediate & 5 & 240 \\
\hline Quercus velutina & black oak & intermediate & 2 or 3 & 109 \\
\hline Robinia pseudoacacia & black locust & intolerant & 3 & 144 \\
\hline Ulmus alata & winged elm & tolerant & 5 & 240 \\
\hline
\end{tabular}

Notes: Shade tolerance classification comes from Lorimer (1983), Burns and Honkala (1990), and Harlow et al. (1991). Taxonomy follows Kartesz (1994).

$\dagger$ Due to a low germination rate only 35 Acer barbatum seedlings were planted; thus, in 13 of the 48 plots, A. barbatum was replaced with an individual of another species.

1950, Christensen and Peet 1981), and dense stands persist for several decades before being replaced by mixed hardwood forests (Oosting 1942, Christensen and Peet 1984). Pinus taeda is a major commercial species in the southeastern United States, where it dominates $\sim 11.7 \times 10^{6}$ hectares (Burns and Honkala 1990, Harlow et al. 1991).

The section of the Duke Forest that forms the FACE experiment was farmed a century ago, and the current plantation was established after a regenerating forest was clear cut. This forest contains a subcanopy of Liquidambar styraciflua, Liriodendron tulipifera, Ulmus alata, and Acer rubrum; these and $>13$ other tree species occur as seedlings and saplings in the forest (Mohan 2002). Soils are infertile Ultic Alfisols, which are widespread in the Piedmont of North Carolina $\left(35^{\circ} 97^{\prime} \mathrm{N} 79^{\circ} 09^{\prime} \mathrm{W}\right)$.

To determine the effects of atmospheric $\mathrm{CO}_{2}$ on understory plants during the summer of 1997 we located eight subplots $\left(1.44 \mathrm{~m}^{2}\right.$ each $)$ in the periphery of each of the six FACE plots $(N=48)$. To minimize the destructive impact of white-tailed deer (Odocoileus virginianus) on the understory vegetation, we surrounded the subplots with $0.9-\mathrm{m}$ tall herbivore exclosures constructed from $2.54-\mathrm{cm}$ wire mesh and fastened to the ground with $13-\mathrm{cm}$ stainless steel ground staples (Forestry Suppliers, Jackson, Mississippi, USA). Note that during this study, mean global $\mathrm{CO}_{2}$ rose from $<360$ $\mu \mathrm{L} / \mathrm{L}$ air to $\sim 380 \mu \mathrm{L} / \mathrm{L}$ air; but for the sake of simplicity all ambient $\mathrm{CO}_{2}$ levels in the text and figures of this paper are denoted by $365 \mu \mathrm{L} / \mathrm{L}$ and elevated concentrations by $565 \mu \mathrm{L} / \mathrm{L}$.

During the autumn of 1997, seeds from 14 tree species (Table 1) were obtained from several maternal trees per species and stratified at $4{ }^{\circ} \mathrm{C}$. These species typically cooccur in Piedmont forests of the southeastern United States (Martin et al. 1993). Seeds of Prunus serotina were scarified with sand paper and Cercis canadensis seeds were soaked overnight in a $10 \%$ solution of $\mathrm{KOH}$. Seeds were planted in germination trays in March 1998 and watered twice daily. They were fertilized daily for 30 days with half-strength Hoagland's fertilizer (Downs and Hellmers 1978). In April, seedlings were moved outside under filtered light conditions and planted individually into $226-\mathrm{cm}^{3}$ "cone-tainers" (Stuewe and Sons, Corvallis, Oregon, USA) filled with Metro-Mix 200 (vermiculite, sphagnum, and perlite; The Scotts Company, Marysville, Ohio, USA), a non-nutritive planting medium. The seedlings were watered once a day with tap water and during natural precipitation events and were no longer supplied with fertilizer.

In October 1998, 49 seedlings representing the 14 tree species were planted into each of the 48 caged subplots (total number of seedlings $=2352$; Table 1). For each species, subplots contained equal numbers of individuals, with the exceptions of Acer barbatum and Quercus velutina that had relatively low germination rates. Within a species, individual seedlings were randomly assigned to each subplot. Within each subplot, the location of each individual on a $7 \times 7$ plant grid was randomly determined. Seedlings were planted during or soon after rain events over a five-day period. To determine transplant success and initial plant size, we measured survivorship, height, and basal diameter (diameter at 5-cm height) of the seedlings two months after transplanting (December 1998) and found posttransplantation survivorship to be high $(93-100 \%$ per species and $\mathrm{CO}_{2}$ treatment). Non-planted vegetation was removed from each plot during annual weeding. Dormant season survivorship and size censuses were repeated annually through 2003.

The supplemental $\mathrm{CO}_{2}$ source used in the elevated plots is derived from the combustion of natural gas, and contains a highly depleted $\delta^{13} \mathrm{C}$ signature of $-43 \%$. The $\mathrm{CO}_{2}$ concentrations in the ambient and fumigated plots are monitored down to only about $1 \mathrm{~m}$ from the soil surface, which was higher than the initial heights of the tree seedlings by approximately an order of magnitude. 
To assess the adequacy and accuracy of the $\mathrm{CO}_{2}$ fumigation of the understory stratum, we harvested current-year leaves of Lonicera japonica (Japanese honeysuckle) at $\leq 15 \mathrm{~cm}$ from the soil surface in each subplot in July 1997. Globally, $\mathrm{C}_{3}$ plants are depleted in ${ }^{13} \mathrm{C}$ relative to the $\mathrm{CO}_{2}$ of the atmosphere due to photosynthetic fractionation, and have foliar $\delta^{13} \mathrm{C}$ values around $-28 \%$ (O'Leary 1988). Our ambient-plot plants exhibited a signature of $-33 \%$ (Fig. 1). This depletion under Duke FACE ambient conditions exceeds the average $\delta^{13} \mathrm{C}$ signature of $\mathrm{C}_{3}$ plants $(-28 \%)$ due to soil respiration, which releases $\mathrm{CO}_{2}$ with a depleted $\delta{ }^{13} \mathrm{C}$ signature from the soil surface where these plants occurred (Andrews et al. 1999). Using the difference between the foliar $\delta^{13} \mathrm{C}$ signatures in ambient and fumigated plots and the $-8 \%$ of the ambient atmosphere in a mass-balance equation (see Appendix A for details of the equation), we calculated a $\mathrm{CO}_{2}$ concentration of $580 \mu \mathrm{L} / \mathrm{L}$ in the understory of fumigated plots. Given the low coefficients of variation of the ambient and elevated foliar $\delta^{13} \mathrm{C}$ signatures $(0.85 \%$ and $2.09 \%$, respectively; Fig. 1$)$, these $\delta^{13} \mathrm{C}$ values indicate that $\mathrm{CO}_{2}$ levels within the elevated plots were reasonably well controlled.

We used hemispherical canopy photographs obtained during uniform sky conditions (cloudy days, early morning, or late afternoon) to estimate understory light conditions at each subplot. Photos were taken in late summer during maximum canopy leaf area from a height of $1 \mathrm{~m}$ above each seedling plot. Images were obtained on 400-speed color slide film using a Nikon FM2 camera with a Sigma $8-\mathrm{mm} 180^{\circ}$ fish-eye lens and leveling tripod. Digitally scanned images were analyzed with the HemiView Canopy Analysis Software (Version 2.1, Delta-T Devices, Cambridge, UK). Photo analysis involves a user-defined threshold intensity for each photo that determines whether pixels are classified as open (sky) or obscured (canopy). The Global Site Factor (GSF) represents the proportion of full sunlight reaching the forest understory, and is used as the "light availability" term in the Bayesian analyses. The GSF combines direct and diffuse radiation but does not account for backscatter within the canopy (Rich 1989, Clark et al. 2003).

In 1998, in order to examine individual growth responses to a range of light conditions, we established four locations in the pine forest surrounding the FACE plots (two to the north and two to the south of the FACE facility) where we manually cleared $20-\mathrm{m}$ diameter canopy gaps. In addition, we used a fifth 10$\mathrm{m}$ diameter gap that was manually cleared in the previous year near the center of the FACE facility. In the center of each of the five gaps we positioned four 1.44- $\mathrm{m}^{2}$ caged subplots along an east-west transect. In October 1998 we planted, enclosed, and monitored each subplot in the same manner as with the subplots in the FACE plots, with the exception that we had no Acer barbatum or Quercus velutina seedlings. We took

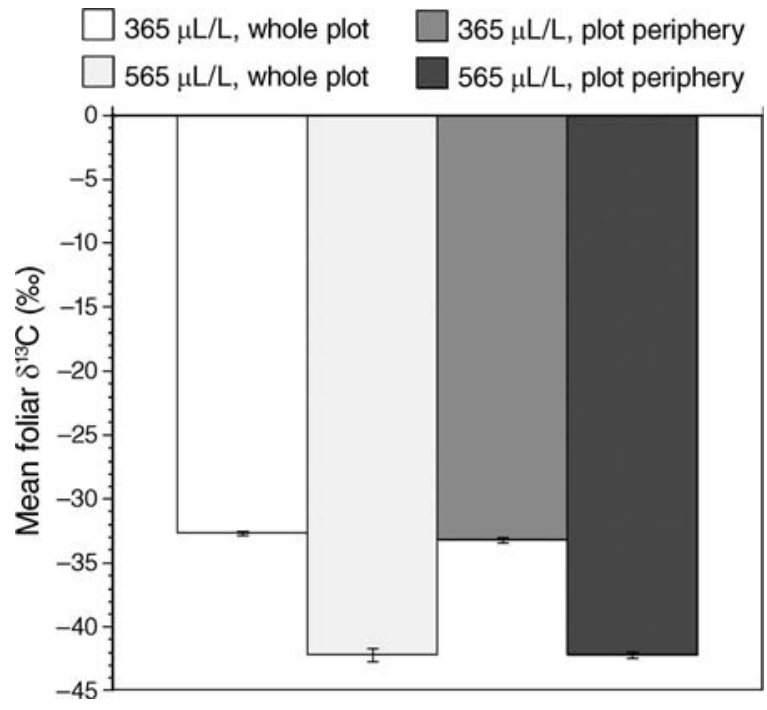

FIG. 1. Mean $\delta^{13} \mathrm{C}$ from foliage samples of Lonicera japonica growing in the FACE understory. Three of the plots are maintained at ambient $\mathrm{CO}_{2}$ concentrations $(\sim 365 \mu \mathrm{L}$ $\mathrm{CO}_{2} / \mathrm{L}$ air), and three of the plots are maintained at elevated $\mathrm{CO}_{2}$ concentrations $(\sim 565 \mu \mathrm{L} / \mathrm{L})$. Within each plot, eight plants growing in the position of proposed subplots ("plot periphery") and 16 plants from random locations within each plot ("whole plot") were used to test the adequacy of the $\mathrm{CO}_{2}$ control. Bars represent plot means $(N=3)$, and error bars denote \pm SE. Elevated $\mathrm{CO}_{2}$ means $(565 \mu \mathrm{L} / \mathrm{L}$ air $)$ are different from ambient $\mathrm{CO}_{2}$ means $(365 \mu \mathrm{L} / \mathrm{L} ; P<0.004)$, but there is no effect of position within each plot. The supplemental $\mathrm{CO}_{2}$ has a $\delta^{13} \mathrm{C}$ signature of $-43 \pm 1 \%$. The depletion under ambient conditions, which exceeds the average $-28 \%{ }^{13} \mathrm{C}$ signature of $\mathrm{C}_{3}$ plants, is due to soil respiration that increases $\mathrm{CO}_{2}$ concentrations and depletes $\delta^{13} \mathrm{C}$ signatures at the soil surface, where these plants occurred (Andrews et al. 1999).

hemispherical photos in 1998 and 1999, but due to the inherently fast growth of these trees under the high-light conditions, we harvested all aboveground biomass from the four larger gaps in November 1999. Many of the harvested individuals produced coppice sprouts the following year, but these were not included in the present study. Individuals in the fifth smaller, darker gap had slower growth rates and were censused through autumn 2001. Data from individuals growing in the gap environments were used in the Bayesian analyses of growth vs. light and $\mathrm{CO}_{2}$, but not in the classical growth analyses in order to focus on $\mathrm{CO}_{2}$ effects in the forest understory.

\section{Analysis of plant growth}

The mean annual relative growth rate (RGR) of seedlings was calculated based on allometric estimates of individual plant aboveground biomass $b_{i j k t}$ (Appendix B)

$$
\mathrm{RGR}_{i j k, t+1}=\ln b_{i j k, t+1}-\ln b_{i j k, t}
$$

where $b$ is the biomass of seedling $i$ in subplot $j$ of plot $k$ in year $t$. Plots were then averaged to calculate the $\mathrm{CO}_{2}$ 
effect on individual plant RGR $(N=3)$. For the ambient treatment

$$
\mathrm{RGR}_{\mathrm{A}}=\sum_{t} \sum_{k \in\{\mathrm{A}\}} \sum_{j} \sum_{i} \mathrm{RGR}_{i j k, t}
$$

where $\{\mathrm{A}\}$ is the set of three plots subjected to the ambient treatment. A similar mean was calculated for the elevated treatment. RGR was calculated only for plants growing in the FACE plots, not on trees planted in the canopy gap environments, in order to focus on potential effects of atmospheric $\mathrm{CO}_{2}$ for understory plant growth. We used repeated-measures multivariate analysis of variance (MANOVA) to examine $\mathrm{CO}_{2}$ effects on mean RGR for the 12 hardwood species over the five years of growth (SAS 1990). We restricted the analyses to the first two years of growth for the pine species, because most had died by 2001 or existed in only one plot.

Our hierarchical Bayes framework allowed us to accommodate (1) the uncertainty in light available to seedlings, and (2) the random variability among seedlings within a species in how they respond to light and $\mathrm{CO}_{2}$. The basic process model describes how plant height or biomass changes from year to year, depending on available light and atmospheric $\mathrm{CO}_{2}$ concentration. We build on the model used by Clark et al. (2003), allowing that light availability is imprecisely known and that each plant within a given group may differ in its response (referred to as "random individual effects" within a population). The model can be viewed as a nonlinear mixed model that is hierarchical in terms of growth response to light. We allow for fixed $\mathrm{CO}_{2}$ effects only, because each individual is subjected to only one $\mathrm{CO}_{2}$ level, and there are only two $\mathrm{CO}_{2}$ treatments.

Let $y_{i j k t}$ be the annual height increment $(\mathrm{cm} / \mathrm{yr})$ or biomass increment ( $\mathrm{g} / \mathrm{yr}$ ) of seedling $i$ in subplot $j$ of plot $k$ in year $t$. There is a mean response $\mu_{i j k t}$ and normally distributed error $\varepsilon_{i j k t}$

$$
y_{i j k t}=\mu_{i j k t}+\varepsilon_{i j k t} .
$$

The mean response is a saturating function of light availability $\mathbf{l}_{j k t}$

$$
\mu_{i j k t}=\mathbf{g}_{i j k}\left(\frac{\mathbf{l}_{j k t}-\mathbf{l}_{c}}{\mathbf{l}_{j k t}+\theta}\right) .
$$

There is an asymptotic growth rate $\mathbf{g}_{i j k}$, a minimum light requirement or light compensation point for nonnegative growth $\mathbf{l}_{c}$ for ambient $\left(\mathbf{l}_{365}\right)$ and elevated $\left(\mathbf{l}_{565}\right)$ $\mathrm{CO}_{2}$ treatments, and a half-saturation constant $\theta$ that describes the light level at which growth is at half the maximum rate.

We fit models representing the four combinations of $\mathrm{CO}_{2}$ and individual random effects, and used predictive loss (Gelfand and Ghosh 1998) as a model selection tool. The four combinations are: (A) neither $\mathrm{CO}_{2}$ nor random individual effects, (B) random individual effects, (C) $\mathrm{CO}_{2}$ effects, and (D) both $\mathrm{CO}_{2}$ and random individual effects. The full model $\mathrm{D}$ is:

$$
\begin{aligned}
& p\left[\mathbf{g}, \mathbf{l}, \mathbf{l}_{350}, \mathbf{l}_{550}, \sigma^{2}, \theta, \alpha, v_{m} \mid \mathbf{y}, \mathbf{l}^{(\mathrm{obs})}, \mathbf{c}\right] \\
& \propto \prod_{k=1}^{6} \prod_{j=1}^{m_{k}} \prod_{i=1}^{n_{j k}} N_{T_{i j k}}\left(\mathbf{y}_{i j k} \mid \mu_{i j k}, \sigma^{2} \mathbf{I}_{T_{i j k}}\right) \\
& \quad \times \prod_{k=1}^{6} \prod_{j=1}^{m} \operatorname{Unif}\left(\mathbf{l}_{j k} \mid a_{j k}, b_{j k}\right) \\
& \quad \times \prod_{k=1}^{6} \prod_{j=1}^{m_{k}} \prod_{i=1}^{n_{k j}} \mathrm{LN}\left[\mathbf{g}_{i j k} \mid \ln (\alpha), v_{m}\right] \operatorname{Unif}\left(\mathbf{l}_{350} \mid a_{\mathbf{l}}, b_{\mathbf{l}}\right) \\
& \quad \times \operatorname{Unif}\left(\mathbf{l}_{550} \mid a_{\mathbf{l}}, b_{\mathbf{l}}\right) \operatorname{Unif}\left(\alpha \mid a_{\alpha}, b_{\alpha}\right) \operatorname{Unif}\left(\theta \mid a_{\theta}, b_{\theta}\right) \\
& \quad \times \operatorname{IG}\left(\sigma^{2} \mid a_{\sigma}, b_{\sigma}\right) \operatorname{IG}\left(v_{m} \mid a_{v}, b_{v}\right)
\end{aligned}
$$

where $\mathbf{l}^{(\text {obs })}$ is the observed light value from the hemispherical photo analysis and $\mathbf{c}$ is the $\mathrm{CO}_{2}$ concentration. For a complete description of the hierarchical Bayesian analysis, see Appendix C. For this study, we focus our attention on $\mathbf{g}$, the set of maximum growth rates $\mathbf{g}_{i j k}$ that vary among individuals; $\mathbf{l}_{c}$, the "light compensation point" (more precisely, the estimated light level where growth rate is zero for this model of plant growth); and $\theta$, the light level at which growth is half of maximum. Models $\mathrm{A}$ and $\mathrm{C}$ have a single parameter $\mathbf{g}$ for each species (because they do not contain random individual effects), and so do not include priors $\alpha$ and $v_{m}$. Models $\mathrm{A}$ and $\mathrm{B}$ have a single parameter value $\mathbf{I}=$ $\mathbf{I}_{365}=\mathbf{I}_{565}$ (because $\mathrm{CO}_{2}$ effects are not taken into account in these models). When the hierarchical model (B) and the hierarchical plus $\mathrm{CO}_{2}$ model (D) have similar $d_{m}$ values (this was the case for Cercis and Pinus echinata), we show only the parameter estimates from model D (for both of these species, models $\mathrm{B}$ and $\mathrm{D}$ had similar predictive loss, $d_{m}$, values, which were an order of magnitude less than the $d_{m}$ values for models $\mathrm{A}$ and C).

Note that $\mathbf{l}_{365}, \mathbf{l}_{565}$, and $\theta$ estimates for Pinus species are low, in part due to the high mortality of these trees at all light levels. Pines have a disproportionately large number of observations from the first year (when they were still alive), and thus a more even distribution of light values than species that tended to die sooner at lower light levels but persisted over the six years of the study.

\section{Survival}

Effects on survival were estimated using the Cox proportional hazard model. The mortality risk for an individual in year $t$ is the product of base hazard $h_{0}$ and covariate effects

$$
h_{i j k t}=h_{0} \exp \left(\mathbf{x}_{i j k t} \beta\right)
$$

where $h_{0}$ is the baseline hazard, $\mathbf{x}_{i j k t}$ is the covariate row vector of growth rate $(\mathrm{cm} / \mathrm{yr}$, used in the Bayesian analysis), light fraction $\mathbf{l}_{j t}$, and $\mathrm{CO}_{2}\left(\log _{10}\left[\mathrm{CO}_{2} / 365\right]\right)$, and $\beta$ is the parameter vector.

\section{Sample biomass}

The combined effects of growth and mortality were assessed from aboveground biomass ( $\mathrm{g}$ ) of surviving 
TABLE 2. Mean annual relative growth rates (RGR) of plants calculated on an individual plant basis and then averaged across plots $(N=3)$.

\begin{tabular}{|c|c|c|c|}
\hline Species & $\begin{array}{l}\text { Mean annual RGR } \\
\text { at } 365 \mu \mathrm{L} / \mathrm{L} \dagger\end{array}$ & $\begin{array}{l}\text { Mean annual RGR } \\
\text { at } 565 \mu \mathrm{L} / \mathrm{L} \dagger\end{array}$ & $\begin{array}{l}\text { Difference in mean RGR } \\
\text { at } 565 \text { vs. } 365 \mu \mathrm{L} / \mathrm{L}(\%)\end{array}$ \\
\hline Acer barbatum & $0.5092(0.08240)$ & $0.5604(0.07579)$ & +10.05 \\
\hline Acer rubrum & $0.1513(0.03705)$ & $0.1772(0.02272)$ & +17.14 \\
\hline Cercis sp. & $0.1252(0.1293)$ & $0.1239(0.1486)$ & -1.031 \\
\hline Liriodendron sp. & $0.2525(0.06349)$ & $0.2322(0.07667)$ & -8.062 \\
\hline Liquidambar sp. & $0.2166(0.09788)$ & $0.2540(0.0693)$ & +17.28 \\
\hline Pinus echinata & $0.4210(0.1522)$ & $0.5351(0.0134)$ & +27.13 \\
\hline Pinus taeda* & $0.4376(0.1377)$ & $0.6351(0.1398)$ & +46.75 \\
\hline Prunus sp. & $0.2633(0.1236)$ & $0.3115(0.1728)$ & +17.83 \\
\hline Quercus alba* & $0.2945(0.06996)$ & $0.3224(0.07369)$ & +9.492 \\
\hline$Q$. phellos & $0.1162(0.04039)$ & $0.1525(0.04287)$ & +31.19 \\
\hline Q. rubra & $0.1227(0.03752)$ & $0.1490(0.05117)$ & +21.45 \\
\hline Q. velutina & $0.2307(0.07022)$ & $0.2388(0.06808)$ & +3.516 \\
\hline Robinia sp.** & $0.1879(0.1147)$ & $0.6200(0.1366)$ & +230.0 \\
\hline Ulmus sp.* & $0.1154(0.03624)$ & $0.1618(0.06005)$ & +20.53 \\
\hline
\end{tabular}

Notes: Terms in parentheses are standard errors. For all hardwood species the data represent means over five growing years; but due to high mortality, the analysis for Pinus species includes only the first two years of growth.

$* P<0.05 ; * * P<0.01$ for the $\mathrm{CO}_{2}$ term in repeated-measures MANOVA.

$\dagger$ These columns report RGR for ambient $\mathrm{CO}_{2}$ volume per liter of air and elevated $\mathrm{CO}_{2}$ volume per liter of air $(365 \mu \mathrm{L} / \mathrm{L}$ and 565 $\mu \mathrm{L} / \mathrm{L}$, respetively).

sample trees, using species-specific allometric equations that relate biomass to height and basal diameter. Allometric coefficients were estimated from similarly sized plants harvested in the forest surrounding the FACE plots (Appendix B). A previous meta-analysis (Curtis and Wang 1998) and data from naturally recruited tree seedlings at this site (J. E. Mohan, unpublished data) suggest that $\mathrm{CO}_{2}$ does not alter plant allometric relationships. "Sample biomass" $B_{k t}$ (in grams) was defined as the aboveground biomass summed over all survivors of a species in each ambient and elevated $\mathrm{CO}_{2}$ plot $(N=3)$, where $i=$ seedling, $j=$ subplot, $k=$ plot, and $t=$ year:

$$
B_{k t}=\sum_{j} \sum_{i} b_{i j k t}
$$

We used repeated-measures multivariate analysis of variance (MANOVA) to examine sample biomass per plot over time (Sokal and Rohlf 1995). Rates of biomass accumulation were analyzed using the $\mathrm{CO}_{2} \times$ year interaction term. We applied square-root transformation of biomass values to meet assumptions of normality and homoscedasticity (Sokal and Rohlf 1995). For species-specific repeated-measures of sample biomass, we used univariate tests of hypotheses because the number of dependent variables (six years of biomass measurements) was not less than the number of observations (six plots). In these cases, we based our interpretations on the Huynh-Feldt Epsilon correction of probabilities in ordinary $F$ tests (Huynh and Feldt 1976, SAS 1990). Relative biomass accumulation per plot is obtained by dividing the total biomass remaining in the plot in 2003 by the initial biomass in 1998. This quotient was compared for ambient and elevated plots. We used two-sided Student's $t$ tests to test the hypothesis that relative accumulation was different under elevated $\mathrm{CO}_{2}$ conditions.

\section{RESULTS}

\section{Growth responses of individual plants to elevated atmospheric $\mathrm{CO}_{2}$}

Most trees showed little effect of $\mathrm{CO}_{2}$ treatment on mean relative growth rate (RGR). When mean annual RGR was analyzed over the five years, individuals of only three species showed a significant response to $\mathrm{CO}_{2}$ : Ulmus alata $(+21 \%)$, Quercus alba $(+9.5 \%)$, and nitrogen-fixing Robinia ( $+230 \%$; Table 2). Pinus taeda seedlings showed a $47 \%$ growth stimulation from elevated $\mathrm{CO}_{2}$ during the first two years of the study, but only one seedling survived to 2002. When the effects of understory light availability and random individual plant variation are included in a hierarchical Bayesian analysis of absolute height growth, the effects of $\mathrm{CO}_{2}$ on plant growth are small relative to variability in response within populations (Fig. 2). However, several species displayed growth benefits from elevated $\mathrm{CO}_{2}$ (i.e., higher growth rates and decreased minimum light requirement). Among shade-intolerant taxa, Liquidambar and Liriodendron had lower light compensation points (I) for growth at elevated $\mathrm{CO}_{2}$ (Tables 3 and 4). For Liquidambar, $\mathbf{I}$ under elevated $\mathrm{CO}_{2}\left(\mathbf{l}_{565}\right)$ was less than half that of growth under ambient $\mathrm{CO}_{2}$ conditions $(1.8 \%$ vs. $3.7 \%$ full sunlight, respectively). Beneficial effects of elevated $\mathrm{CO}_{2}$ on the growth of Quercus velutina, a species of intermediate tolerance, were seen in a light compensation point at high $\mathrm{CO}_{2}$ that was less than half of $\mathbf{l}_{365}(0.22 \%$ vs. $0.47 \%)$.

Four of the five species classed as shade tolerant displayed growth benefits from elevated $\mathrm{CO}_{2}$. Acer barbatum and $A$. rubrum exhibited small increases in growth, particularly at light levels less than $\sim 30 \%$ full 

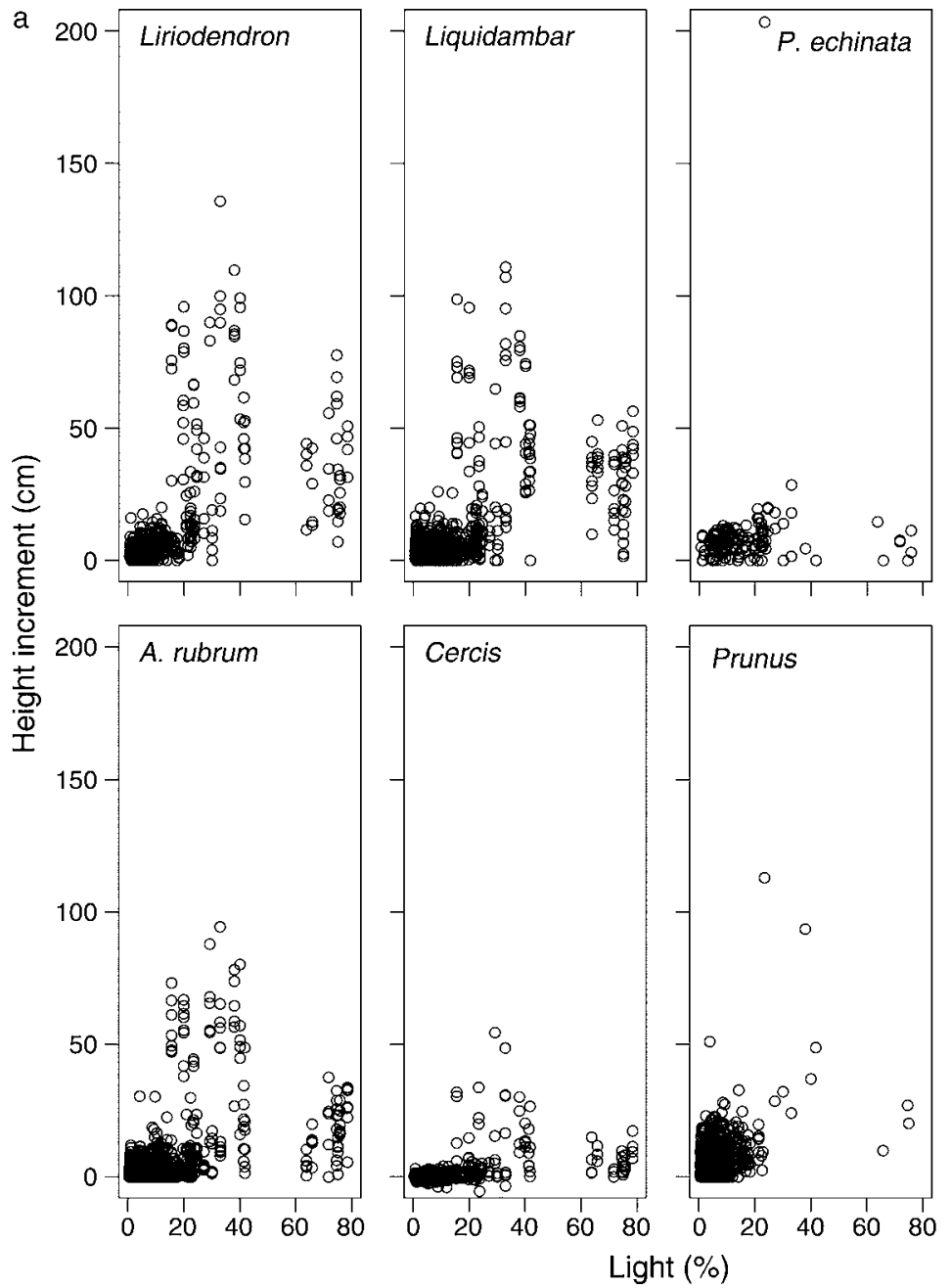
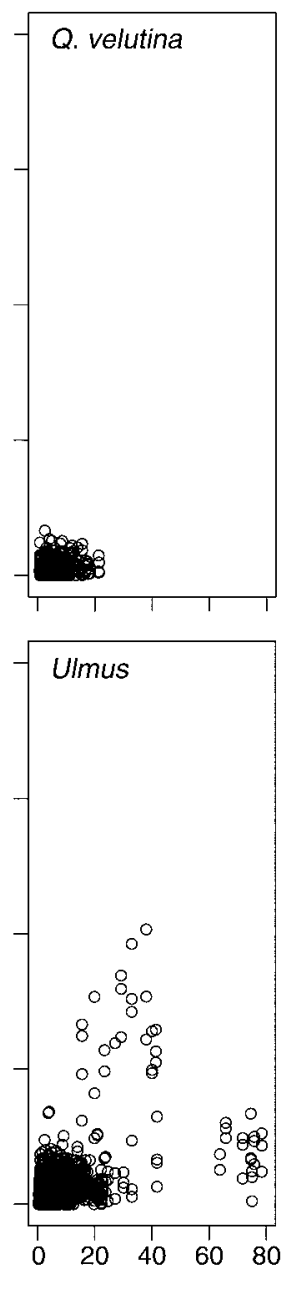

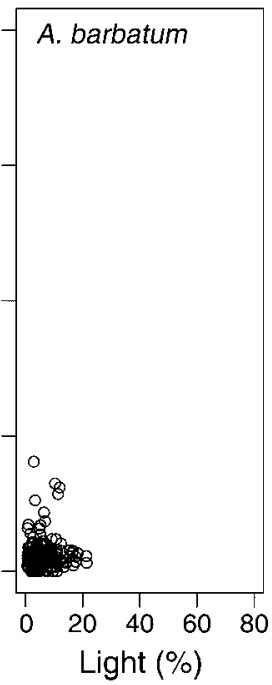

FIG. 2. Height growth increment ( $y$-axis) vs. available light (percentage of full sunlight, $x$-axis) for species exhibiting individual plant growth responses to $\mathrm{CO}_{2}$ (species that had Model $\mathrm{C}$ or D as the best fit in Table 3). Panel (a) depicts the growth data for individual trees and years depicted by small circles. Panel (b) shows model fits, where solid lines represent ambient $\mathrm{CO}_{2}$ conditions and dashed lines represent elevated $\mathrm{CO}_{2}$. For each $\mathrm{CO}_{2}$ treatment, there are five lines. The middle line shows the posterior median height increment. Moving outward from this central line, the next lines represent parameter uncertainty (95\% credible intervals). The outermost lines include random individual effects.

sunlight (Fig. 2), and decreases in light compensation points $(0.74 \%$ vs. $1.8 \%$ for $A$. barbatum, and $1.4 \%$ vs. $4.6 \%$ for A. rubrum; Table 3). Prunus had faster growth at light levels ranging from $<2 \%$ to $\sim 60 \%$ (Fig. 2), and an $\mathbf{I}_{565}$ that was less than half $\mathbf{I}_{365}(1.8 \%$ vs. $3.8 \%$; Table 3$)$. Finally, Ulmus grew slightly taller at elevated $\mathrm{CO}_{2}$ under the full range of light levels $(\sim 0.10 \%$ to $\sim 78 \%$; Fig. 2$)$ and had an $\mathbf{I}_{565}$ almost half of the $\mathbf{I}_{365}$ value $(2.1 \%$ vs. 3.9\%; Table 3). Model selections for the Bayesian analyses of aboveground plant biomass growth often did not distinguish between $\mathrm{CO}_{2}$ levels, likely because $\mathrm{CO}_{2}$ affected height growth of understory trees in this low light forest more than diameter growth (Table 4). When the importance of random individual variability in growth response is considered, the biggest effect of $\mathrm{CO}_{2}$ was to reduce light compensation points of select species.

\section{Survivorship responses to atmospheric $\mathrm{CO}_{2}$}

Overall survivorship, averaged across individuals of all species, was slightly higher under elevated $\mathrm{CO}_{2}$ conditions (mean ambient survivorship probability in 2003 was $0.49 \pm 0.01$ and mean elevated survivorship probability was $0.55 \pm 0.01$; Fig. 3). Shade-intolerant taxa generally demonstrated low survivorship under both $\mathrm{CO}_{2}$ treatments, whereas shade-tolerant trees typically had high survivorship, but the effect of $\mathrm{CO}_{2}$ on survivorship differed by species (Fig. 4). The strongest impact of atmospheric $\mathrm{CO}_{2}$ on survivorship probability was indirect and mediated through the $\mathrm{CO}_{2}$ effect on growth. For most species, the growth rate in the previous year was the most important predictor of survivorship, followed by light availability (Table 5). After these factors were taken into account in a Cox 

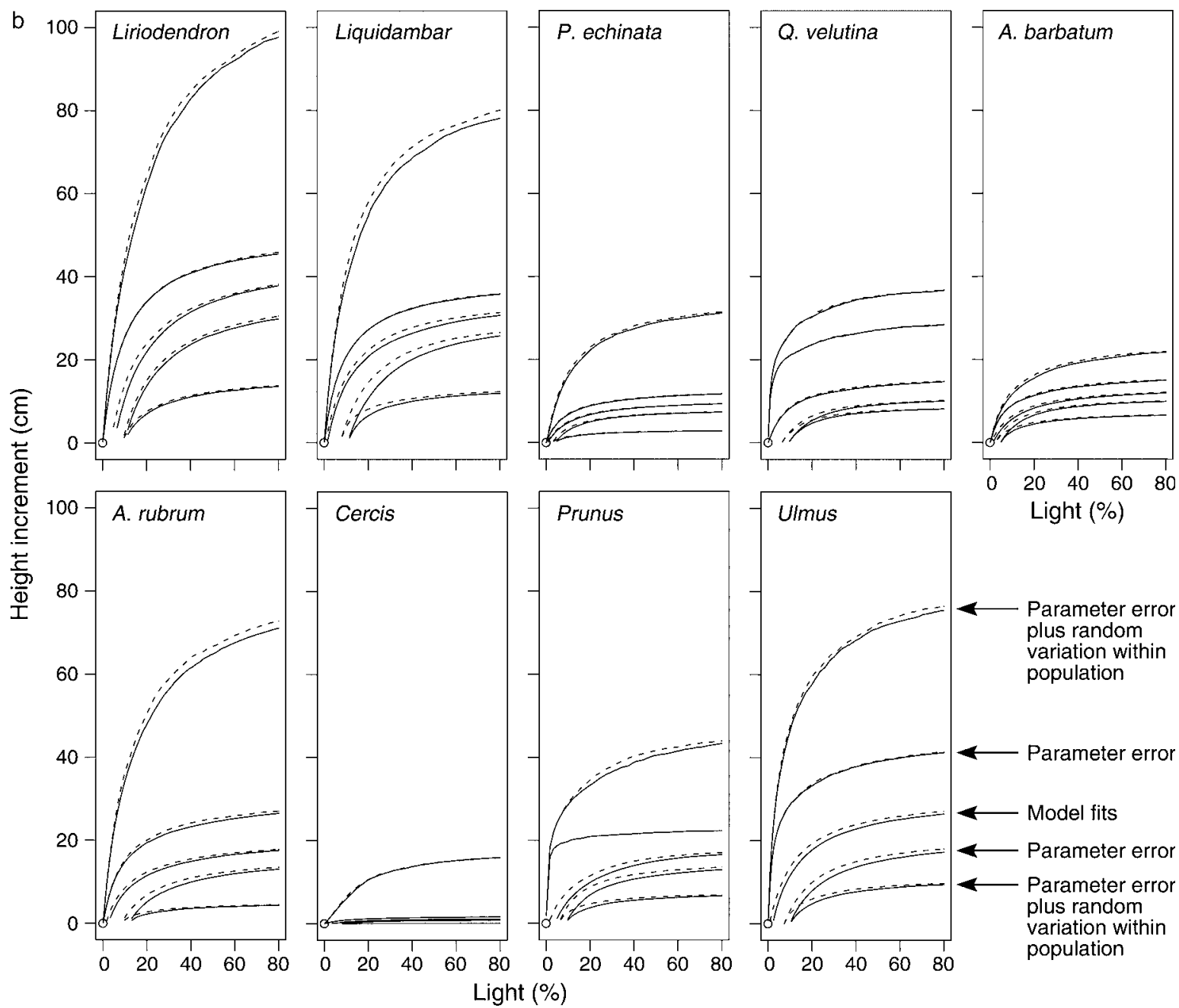

FIG. 2. Continued.

TABLE 3. Parameter estimates from the hierarchical Bayes model that best explains annual height growth increment (cm/yr) for each species.

\begin{tabular}{llccccc}
\hline \hline \multicolumn{1}{c}{ Species } & \multicolumn{1}{c}{$\mathbf{g}_{\max }$} & $\mathbf{l}_{365}$ & $\mathbf{l}_{565}$ & $\theta$ & $\alpha$ & $v_{\mathrm{m}}$ \\
\hline Acer barbatum [D] & $13.9(1.86)$ & $1.78(1.55)$ & $0.740(0.782)$ & $10.0(2.67)$ & $28.9(4.92)$ & $0.116(0.0351)$ \\
A. rubrum [D] & $22.0(4.51)$ & $4.45(4.56)$ & $3.06(3.29)$ & $10.5(2.47)$ & $20.30(367)$ & $0.688(0.143)$ \\
Cercis sp. [D] & $27.4(4.71)$ & $5.42(4.54)$ & $3.71(3.38)$ & $10.5(1.75)$ & $23.4(20.9)$ & $0.656(0.137)$ \\
Liriodendron sp. [D] & $45.3(4.82)$ & $4.78(3.88)$ & $4.04(3.49)$ & $10.5(1.12)$ & $32.6(5.37)$ & $0.340(0.102)$ \\
Liquidambar sp. [D] & $36.2(2.86)$ & $3.66(4.09)$ & $1.83(2.30)$ & $10.3(1.16)$ & $17.5(4.00)$ & $0.323(0.0619)$ \\
Pinus echinata [D] & $10.7(1.51)$ & $1.30(1.41)$ & $0.832(0.972)$ & $9.72(2.22)$ & $24.1(4.74)$ & $0.515(0.143)$ \\
P. taeda [A] & $14.4(0.901)$ & $0.479(0.422)$ & $\ldots$ & $8.4(2.38)$ & $48.2(5.22)$ & \\
Prunus sp. [D] & $19.9(3.02)$ & $3.82(3.28)$ & $1.76(1.91)$ & $9.34(4.14)$ & $38.0(14.6)$ & $0.305(0.0969)$ \\
Quercus alba [B] & $11.0(1.4)$ & $7.05(1.02)$ & $\ldots$ & $8.77(3.52)$ & $15.8(7.56)$ & $0.184(0.0428)$ \\
Q. phellos [A] & $7.76(0.467)$ & $0.132(0.105)$ & $\ldots$ & $9.25(0.943)$ & $7.88(0.499)$ & $\ldots$ \\
Q. rubra [B] & $7.58(0.814)$ & $1.05(1.31)$ & $\ldots$ & $9.24(3.18)$ & $13.8(4.78)$ & $0.494(0.0973)$ \\
Q. velutina [C] & $9.01(0.652)$ & $0.466(0.411)$ & $0.215(0.183)$ & 9.67 & $5.62(0.446)$ & $\ldots$ \\
Robinia sp. [B] & $83.4(10.4)$ & $4.52(2.02)$ & $\ldots$ & $12.5(2.87)$ & $646(106)$ & $0.374(0.160)$ \\
Ulmus sp. [D] & $31.9(7.31)$ & $3.89(3.94)$ & $2.10(2.59)$ & $9.75(3.52)$ & $33.5(487)$ & $0.330(0.102)$ \\
\hline
\end{tabular}

Notes: Values are posterior means with Bayesian standard errors in parentheses. Using predictive loss $\left(d_{m}\right)$, we selected from four possible model combinations: (A) simple model containing neither $\mathrm{CO}_{2}$ effects nor random variation between individuals, (B) hierarchical model accounting for random variation between individuals but not accounting for $\mathrm{CO}_{2}$, (C) simple model containing $\mathrm{CO}_{2}$ effects, and (D) hierarchical model accounting for random variation and differences between $\mathrm{CO}_{2}$ concentrations. Designation of the best model is shown in brackets following each species name.

Explanations of parameters: $\theta$ represents the light level at which growth is half the maximum rate; $\alpha$ and $v_{m}$ are Bayesian priors on $\mathbf{g}_{i j k}$. The asymptotic growth rate $\left(\mathbf{g}_{i j k}\right)$ is lognormal with fixed effect $\alpha$ and variance (on $\log$ growth rate) $v_{m}: \mathbf{g}_{i j k} \sim \operatorname{LN}\left(\ln (\alpha), v_{m}\right)$. 
TABLE 4. Parameter estimates from the model best explaining annual aboveground biomass growth increment (g/yr) for each species.

\begin{tabular}{lcccccc}
\hline \hline \multicolumn{1}{c}{ Species } & $\mathbf{g}_{\max }$ & $\mathbf{l}_{365}$ & $\mathbf{l}_{565}$ & $\theta$ & $\alpha$ & $v_{m}$ \\
\hline Acer barbatum [B] & $0.694(0.210)$ & $0.866 \%(0.875)$ & $\ldots$ & $10.2 \%(3.07)$ & $0.402(0.0546)$ & $0.877(0.570)$ \\
A. rubrum [B] & $1.69(0.488)$ & $3.01 \%(3.39)$ & $\ldots$ & $10.5 \%(2.15)$ & $0.480(11.8)$ & $1.31(0.351)$ \\
Cercis sp. [B] & $1.23(0.356)$ & $3.04 \%(2.37)$ & $\ldots$ & $10.3 \%(1.82)$ & $0.976(1.06)$ & $3.15(0.601)$ \\
Liriodendron sp. [D] & $3.50(0.711)$ & $5.65 \%(3.03)$ & $4.41 \%(2.47)$ & $10.6 \%(2.55$ & $1.89(0.546)$ & $1.53(0.345)$ \\
Liquidambar sp. [D] & $3.33(0.689)$ & $4.13 \%(4.31)$ & $3.01 \%(3.30)$ & $10.5 \%(2.20)$ & $0.481(2.31)$ & $1.07(0.256)$ \\
Pinus echinata [D] & $0.601(0.103)$ & $5.43 \%(4.70)$ & $3.48 \%(3.36)$ & $10.2 \%(5.91)$ & $8.97(59.5)$ & $2.05(0.723)$ \\
P. taeda [B] & $0.836(0.135)$ & $1.84 \%(1.37)$ & $\ldots$ & $9.99 \%(3.16)$ & $0.444(0.0574)$ & $0.482(0.177)$ \\
Prunus sp. [B] & $0.655(0.224)$ & $0.812 \%(0.781)$ & $\ldots$ & $10.1 \%(2.82)$ & $0.919(0.0886)$ & $1.39(0.832)$ \\
Quercus alba [B] & $1.44(0.160)$ & $0.615 \%(0.832)$ & $\ldots$ & $9.42 \%(3.08)$ & $0.664(0.117)$ & $0.306(0.0748)$ \\
Q. phellos [A] & $0.586(0.0548)$ & $0.331 \%(0.293)$ & $\ldots$ & $9.39 \%(2.20)$ & $0.188(0.0114)$ & $\ldots$ \\
Q. rubra [D] & $1.27(0.168)$ & $1.59 \%(1.67)$ & $0.966 \%(1.09)$ & $9.85 \%(3.06)$ & $1.40(0.150)$ & $0.804(0.154)$ \\
Q. velutina [D] & $0.929(0.143)$ & $0.799 \%(0.861)$ & $0.468 \%(0.511)$ & $8.32 \%(3.56)$ & $0.503(0.0536)$ & $0.158(0.0978)$ \\
Robinia sp. [B] & $19.7(4.31)$ & $5.47 \%(1.95)$ & $\ldots$ & $11.5 \%(3.22)$ & $143(21.5)$ & $1.14(0.399)$ \\
Ulmus sp. [B] & $1.23(0.525)$ & $2.45 \%(2.51)$ & $\ldots$ & $10.5 \%(1.87)$ & $0.547(0.159)$ & $1.40(0.398)$ \\
\hline
\end{tabular}

Notes: Using predictive loss $\left(d_{m}\right)$, we selected from four possible model combinations: (A) simple model containing neither $\mathrm{CO}_{2}$ effects nor random variation between individuals, (B) hierarchical model accounting for random variation between individuals but not accounting for $\mathrm{CO}_{2},(\mathrm{C})$ simple model containing $\mathrm{CO}_{2}$ effects, and (D) hierarchical model accounting for random variation and differences between $\mathrm{CO}_{2}$ concentrations. Designation of the best model is shown in brackets following each species name.

See Table 3 for explanation of parameters.

proportional hazards analysis, shade-intolerant Liquidambar, intermediately tolerant $Q$. rubra, and shadetolerant Cercis were more likely to survive at elevated $\mathrm{CO}_{2}$. Thus $\mathrm{CO}_{2}$ does not appear to directly differentially benefit the survivorship of any shade tolerance group. $\mathrm{CO}_{2}$ did not impact survivorship probabilities of the remaining species other than by affecting growth rates for the previous years, and this was particularly true for shade-tolerant taxa.

\section{Sample biomass accumulation responses to atmospheric $\mathrm{CO}_{2}$}

Total sample biomass, which integrates plant growth rates and survivorship across members of a given species, increased over time at both ambient and elevated $\mathrm{CO}_{2}$ conditions (Fig. 5). The rate of increase, however, was greater under high $\mathrm{CO}_{2}\left(P<0.0001\right.$ for the $\mathrm{CO}_{2} \times$

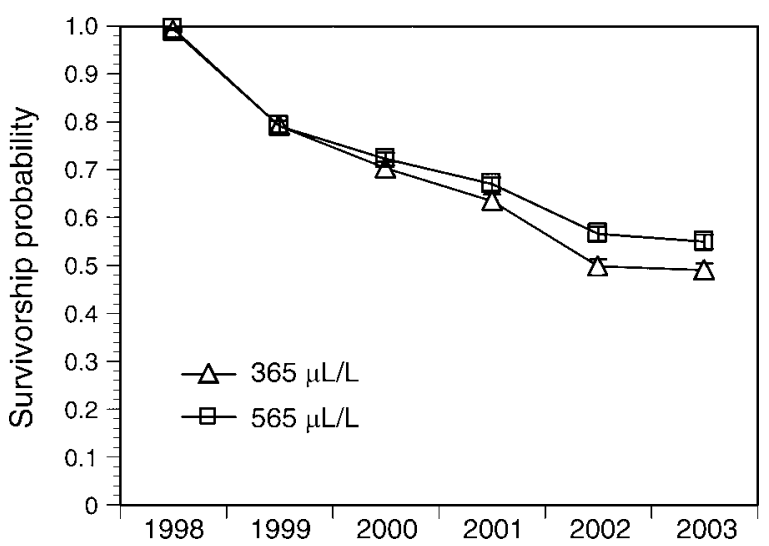

FIG. 3. Cumulative survivorship over six years averaged across individuals of all species under ambient (triangles) and elevated (squares) $\mathrm{CO}_{2}$ treatments at FACE (canopy gap trees not included). Overall, high $\mathrm{CO}_{2}$ plants have slightly greater survivorship. Error bars represent $\pm \mathrm{SE}$. year interaction in a repeated-measures analysis), and elevated plots accumulated relatively more biomass by 2003 ([Biomass $_{2003} /$ Biomass $\left._{1998}\right]$ was $1.60 \pm 0.05$ [mean $\pm \mathrm{SE}]$ under ambient conditions and $2.10 \pm 0.16$ under elevated $\mathrm{CO}_{2}$ conditions; $P=0.02$ ). However, the rate of biomass increase and the relative amount of biomass accumulated varied among species. Most intolerant trees exhibited no effect of $\mathrm{CO}_{2}$ on biomass accumulation (Fig. 6a). Biomass of Pinus taeda, a species that had very low survivorship and had completely died out of the three ambient plots by 2002, declined over time at elevated $\mathrm{CO}_{2}$ and continued to persist in only one of the plots with elevated $\mathrm{CO}_{2}$ by 2003. Nitrogen-fixing Robinia pseudoacacia had a tendency to accumulate biomass faster under elevated $\mathrm{CO}_{2}(P=0.10)$, and by 2003 had a mean biomass at high $\mathrm{CO}_{2}$ that was eight times greater than in control plots, though the difference was not statistically significant $(16 \pm 8 \mathrm{~g}$ vs. $1.8 \pm 0.7 \mathrm{~g} ; P=$ 0.21). All three intermediately tolerant Quercus species accumulated biomass over time but none showed an overall significant effect of $\mathrm{CO}_{2}$ on the rate of growth (Fig. 6b). After six years Quercus rubra had accumulated relatively more biomass when grown under high $\mathrm{CO}_{2}$ ([Biomass $2003 /$ Biomass $\left._{1998}\right]$ equaled $1.52 \pm 0.06$ under ambient conditions and $1.87 \pm 0.08$ under elevated conditions; $P=0.01$ ). Overall, total biomass accumulation of shade-tolerant trees showed the greatest response to $\mathrm{CO}_{2}$ enrichment (Fig. 6c). Acer barbatum and Ulmus alata both increased sample biomass faster under elevated $\mathrm{CO}_{2}(P=0.001$ and 0.005 , respectively; Fig. $6 \mathrm{c})$ and accumulated relatively more biomass when given supplemental $\mathrm{CO}_{2}$ (for $A$. barbatum, [Biomass $2003 /$ Biomass $_{1998}$ ] equaled $12.2 \pm 1.7$ under ambient conditions and $19.9 \pm 1.9$ under elevated conditions $[P=0.018]$; for $U$. alata [Biomass $2003 /$ Biomass $_{1998}$ ] equaled $1.85 \pm 0.19$ under ambient conditions and $2.22 \pm 0.07$ under elevated conditions; $P=0.07)$. 

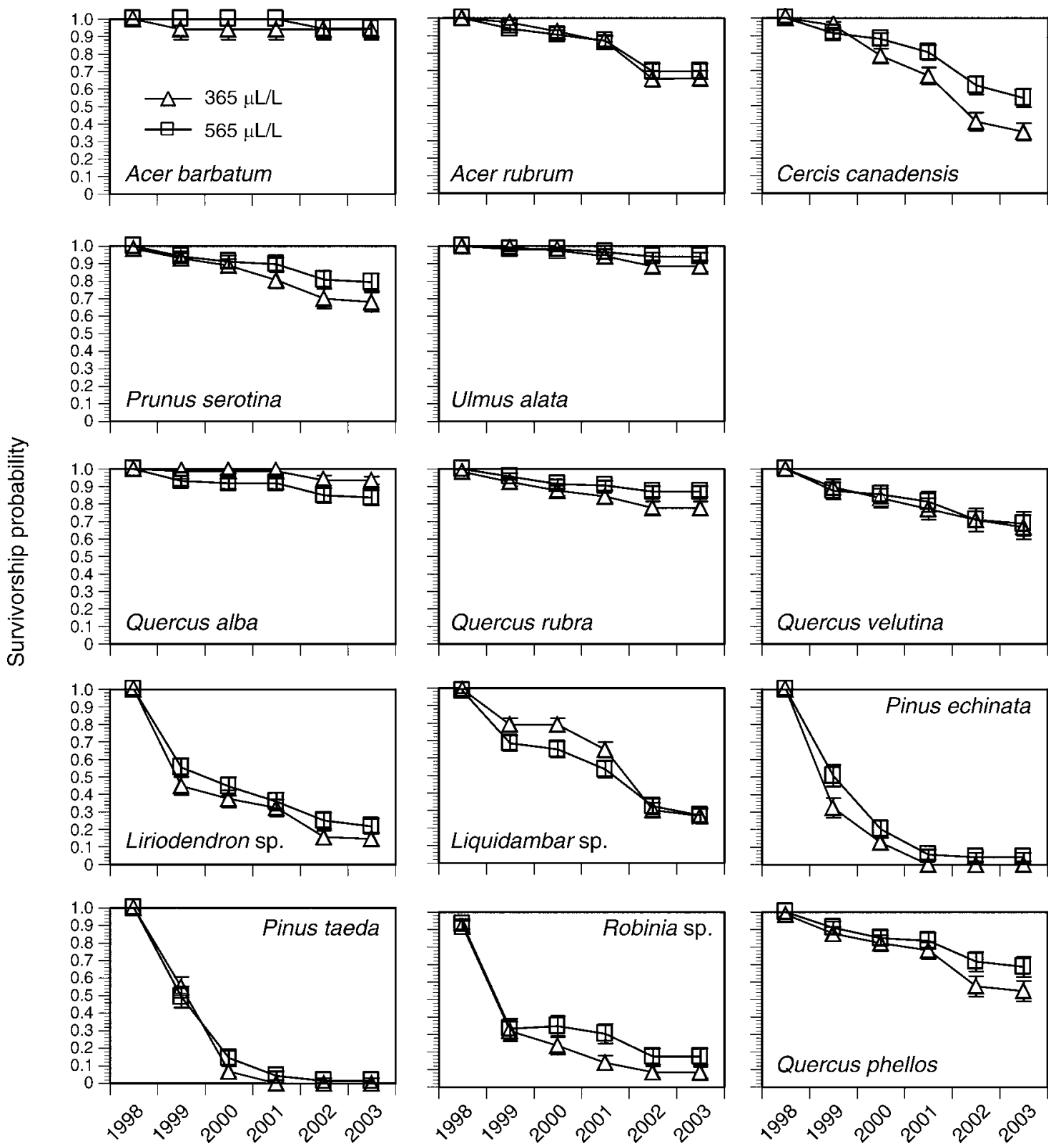

FIG. 4. Mean cumulative survivorship probabilities over six years for individual tree species growing under ambient (triangles) and elevated (squares) $\mathrm{CO}_{2}$ treatments at FACE. Error bars represent $\pm \mathrm{SE}$.

\section{Discussion}

This experimental analysis of forest successional response to elevated $\mathrm{CO}_{2}$ indicates that some tree species, when given supplemental carbon, exhibit small increases in annual growth and are better able to maintain positive growth under the low light conditions typical of forest understory environments (Fig. 2, Tables 2 and 3). Such effects may accumulate over time to affect future demographic patterns of forest trees (Bazzaz 1996, Shaver et al. 2000, Nowak et al. 2004). Speciesspecific effects of $\mathrm{CO}_{2}$ on the growth-light relationship may have particular relevance for future forest dynam- ics, given that light availability explains most of the variation in the growth of temperate forest saplings (Finzi and Canham 2000). However, the effects of $\mathrm{CO}_{2}$ enrichment on tree growth were less than reported in previous studies.

When averaged across species, trees survive better in this shady forest understory given $\mathrm{CO}_{2}$ enrichment, but few individual taxa actually display significant effects of atmospheric $\mathrm{CO}_{2}$ on survivorship (Fig. 4), apart from the impact of $\mathrm{CO}_{2}$ on previous years' growth rate (Table 5; Wyckoff and Clark 2002). Six species exhibited an important indirect effect of $\mathrm{CO}_{2}$ on survivorship 
TABLE 5. Results from the Cox proportional hazards survivorship analyses.

\begin{tabular}{|c|c|c|c|}
\hline \multirow[b]{2}{*}{ Species } & \multicolumn{3}{|c|}{ Coefficient } \\
\hline & Growth & Light & $\mathrm{CO}_{2}$ \\
\hline \multicolumn{4}{|l|}{ Acer barbatum } \\
\hline A. rubrum & $0.412(0.090)^{* * *}$ & & \\
\hline Cercis sp. & $0.165(0.063)^{* *}$ & $10.507(3.910)^{* *}$ & $4.611(1.339)^{* * *}$ \\
\hline Liriodendron sp. & $0.148(0.042)^{* * *}$ & & \\
\hline Liquidambar sp. & $0.0933(0.052) \dagger$ & $19.546(7.173)^{* *}$ & $9.449(3.648)^{* *}$ \\
\hline Pinus echinata & & $7.597(2.980)^{*}$ & \\
\hline P. taeda & & $8.648(1.620)^{* * *}$ & \\
\hline \multicolumn{4}{|l|}{$\begin{array}{l}\text { Prunus sp. } \\
\text { Ouercus alba }\end{array}$} \\
\hline Q. phellos & $0.269(0.105)^{*}$ & & \\
\hline Q. rubra & $0.423(0.117)^{* * *}$ & $6.094(3.152) \dagger$ & $4.774(2.498) \dagger$ \\
\hline Q. velutina & $1.300(0.313)^{* * *}$ & $48.960(11.100)^{* * *}$ & \\
\hline Robinia sp. & $0.106(0.039)^{* *}$ & & \\
\hline Ulmus sp. & $0.226(0.093)^{*}$ & & \\
\hline
\end{tabular}

Notes: Columns depict results of sequential term additions (growth rate in previous year, light level, and $\mathrm{CO}_{2}$ treatment) denoting parameter estimates, with standard errors reported in parentheses. Estimates are order dependent.

$\dagger P<0.10 ; * P<0.05 ; * * P<0.01 ; * * * P<0.001$; cells without numbers showed no significant effect.

("indirect" referring to an effect on survivorship that is mediated through a $\mathrm{CO}_{2}$ effect on growth) by having previous years' growth as an important predictor of survivorship, and also exhibiting greater growth under low light conditions when exposed to supplemental $\mathrm{CO}_{2}$. These included Acer rubrum, Cercis, Ulmus, Quercus velutina, Liriodendron, and Liquidambar. The three species with a significant direct effect of $\mathrm{CO}_{2}$ on survivorship (i.e., Liquidambar, Quercus rubra, and Cercis) cross the range of shade tolerance classifications, so we see no evidence of $\mathrm{CO}_{2}$ differentially impacting the survivorship of different successional functional groups. Further, contrary to our expectation, supplemental $\mathrm{CO}_{2}$ did not enhance the survivorship of most of the shadeintolerant tree species, which at maturity form the most productive forest ecosystems.

When we extrapolate the results from $\mathrm{CO}_{2}$ effects on individual plant growth and survivorship to calculate biomass accumulation rates of species, a proxy for species competitive abilities (Nowak et al. 2004), we find

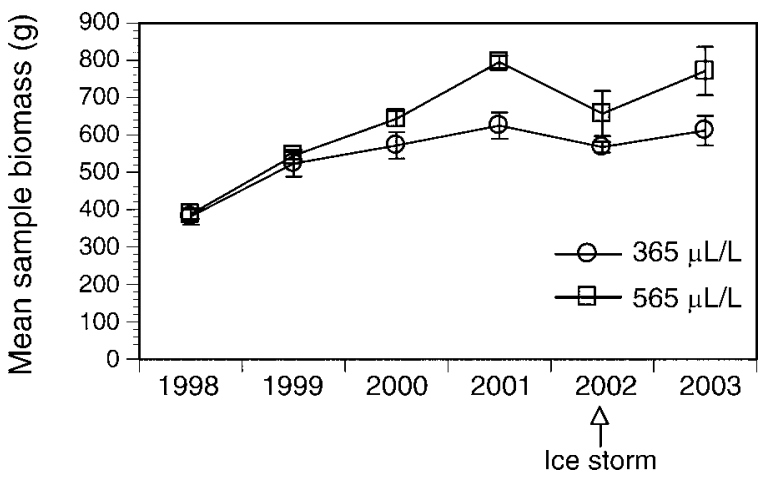

FIG. 5. Mean sample biomass (grams) over time at ambient (circles) and elevated (squares) $\mathrm{CO}_{2}$ treatments at FACE (canopy gap trees not included; $N=3$ ). that total sample biomass accumulates faster under high $\mathrm{CO}_{2}$ (Fig. 5). Overall, understory sample biomass was 26\% larger under elevated $\mathrm{CO}_{2}$ conditions by 2003 $(771 \pm 65 \mathrm{~g}$ [mean $\pm \mathrm{SE}$ ] for elevated vs. $612 \pm 40 \mathrm{~g}$ for ambient $\mathrm{CO}_{2} ; P=0.10$ ). While understory productivity is a small component of current forest NPP (DeLucia et al. 1999), species-specific data can be used to aid forecasts of future competitive outcomes (Bolker et al. 1995, Shaver et al. 2000). Sample biomass of shadeintolerant trees is markedly unresponsive to elevated $\mathrm{CO}_{2}$ (Fig. 6a). Although some shade-intolerant species such as Pinus taeda exhibit increased individual plant growth with $\mathrm{CO}_{2}$ enrichment, this is negated by consistently low survivorship. Due to its relatively low survivorship even under elevated $\mathrm{CO}_{2}$, it is likely that the increased sample biomass of nitrogen-fixing Robinia at high $\mathrm{CO}_{2}$ is a transient response and unlikely to stimulate future forest productivity. Species of intermediate tolerance, Quercus alba and Q. velutina, do not show sample biomass responses to $\mathrm{CO}_{2}$, although after five years $Q$. rubra accumulated relatively more sample biomass at elevated $\mathrm{CO}_{2}$ conditions (Fig. 6b). Shadetolerant tree species show the greatest stimulation of sample biomass from $\mathrm{CO}_{2}$ enrichment (Fig. 6c), particularly Acer barbatum (southern sugar maple) and Ulmus alata (winged elm), subcanopy trees that are typically neither very productive nor large at maturity (Burns and Honkala 1990). The benefit of increased atmospheric $\mathrm{CO}_{2}$ for the success of shade-tolerant tree species in a forested ecosystem supports findings of earlier work using pots and growth chambers (Bazzaz et al. 1990, Bazzaz and Miao 1993, Kubiske and Pregitzer 1996, 1997, Kinney and Lindroth 1997, Kerstiens 1998, 2001, Hättenschwiler and Körner 2000). The most responsive species in terms of sample biomass accumulation, Acer barbatum and Ulmus alata, are also two of the best survivors under ambient $\mathrm{CO}_{2}$ conditions $(94 \pm$ 


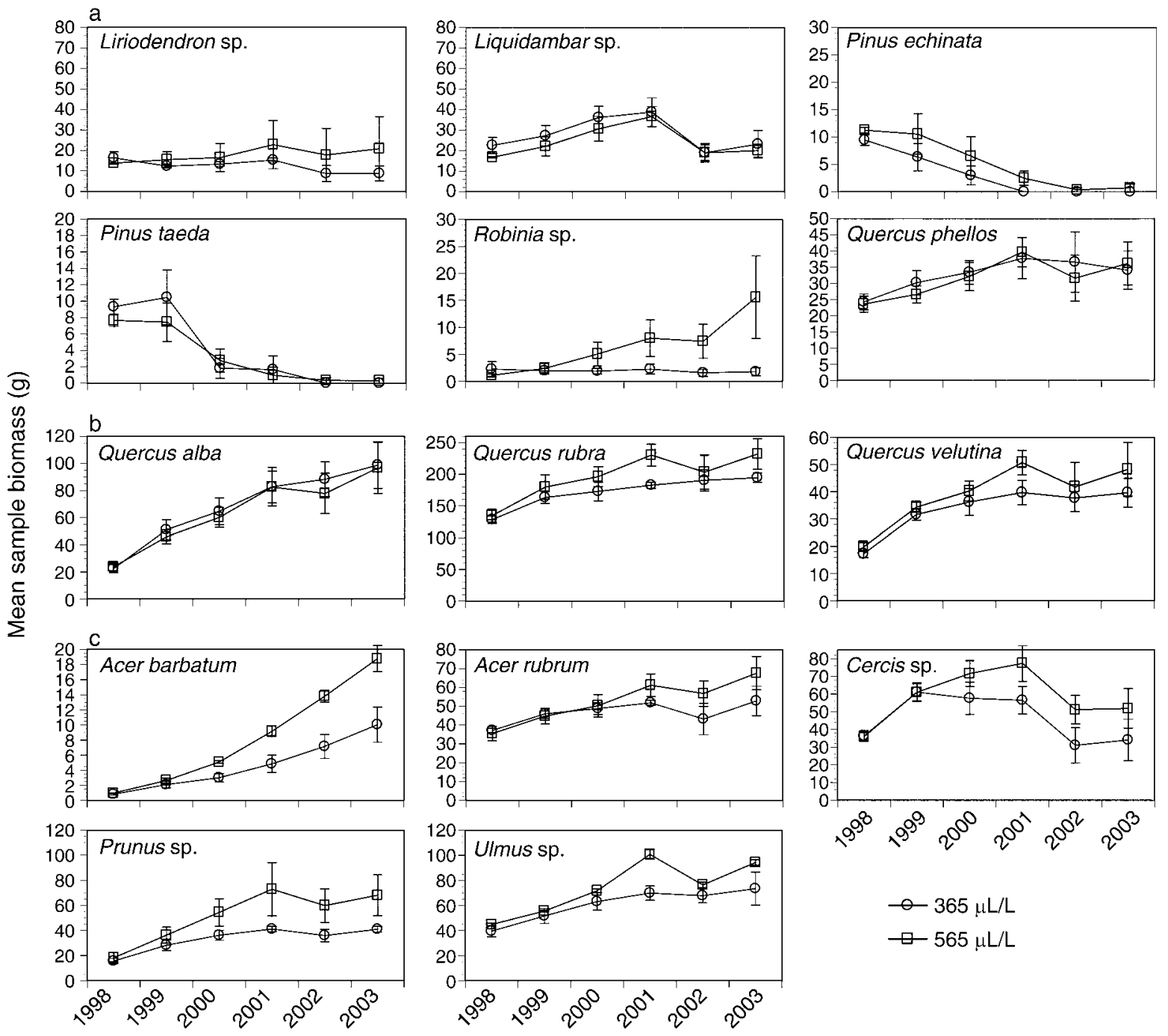

FIG. 6. Mean sample biomass over time for (a) shade-intolerant tree species, (b) intermediately tolerant tree species, and (c) shade-tolerant tree species growing at ambient (circles) and elevated (squares) $\mathrm{CO}_{2}$ treatments at FACE (canopy gap trees not included; $N=3$ ).

$6 \%$ and $88 \pm 3 \%$ surviving, respectively; Fig. 4). Although many studies examining the implications of elevated $\mathrm{CO}_{2}$ on future community composition base conclusions solely on individual plant growth, the present study suggests that low light survivorship is an important predictor of population-scale responses to elevated $\mathrm{CO}_{2}$.

\section{Future IMPLICATIONS}

Although the relative success of juvenile trees is only one phase of forest development, individuals in the "sapling bank" typically have the greatest opportunities of attaining canopy dominance following the death of a single or several canopy trees (Pickett and White 1985). Which individuals reach the canopy is strongly influenced by juvenile growth and survival (Pacala et al. 1996, Landis and Peart 2005). Given the low survivorship of shade-intolerant tree species under both $\mathrm{CO}_{2}$ concentrations, we have no evidence that highly productive stands dominated by such taxa will necessarily represent temperate forests of the future barring human intervention. Our data suggest that elevated $\mathrm{CO}_{2}$ may favor recruitment of less-productive, shade-tolerant tree species, and not cause a large fertilization effect on global forest productivity. This would discount the potential for enhanced forest growth and carbon accumulation to compensate for anthropogenically derived increases in levels of atmospheric $\mathrm{CO}_{2}$ (Idso et al. 1991, Kirschbaum 2003, Deckmyn et al. 2004). If the growth of shade-tolerant juveniles is accompanied by increased mortality of canopy trees, suggested by the faster growth (DeLucia et al. 1999) and earlier ontogenetic development (LaDeau and Clark 2001) of the Pinus taeda canopy at elevated $\mathrm{CO}_{2}$ in the Duke freeair $\mathrm{CO}_{2}$ enrichment (FACE) experiment, forest succession may accelerate. Unlike the prolonged coexistence of 
early- and late-successional species observed with $\mathrm{CO}_{2}$ enrichment of a pasture community (Potvin and Vasseur 1997), and similar to the accelerated successional change seen in a grassland ecosystem (Polley et al. 2003), we find that future competitive dynamics among temperate forest trees may be shifted toward late-successional species.

\section{ACKNOWLEDGMENTS}

G. Hendrey, J. Nagy, and K. Lewin were instrumental in construction and maintenance of the FACE facilities. The following persons provided valuable field assistance: D. LeBauer, P. Frankson, M. Anderson, J. McKellips, J. Pippen, E. Ball, I. Ibanez, A. Carrol, M. Cianfrani, D. Snyder, M. Welsh, R. Mohan, and B. Frankson. We thank the staff of the Duke Forest, and personnel from the Duke University Phytotron and Greenhouses. This work was enhanced by discussions with B. Beckage, P. Camill, N. Christensen, M. Dietze, A. Finzi, J. HilleRisLambers, I. Ibanez, S. LaDeau, M. Lavine, J. Lichter, J. Lynch, J. McLachlan, R. Peet, B. Strain, M. Wolosin, and P. Wyckoff. The manuscript was improved by the suggestions of two anonymous reviewers. This research was supported by the Office of Science (BER), U.S. Department of Energy, Grant No. DE-FG02-95ER62083, and by Terrestrial Ecosystems and Global Change (TECO) Grant No. DE-F602-97ER62463.

\section{Literature Cited}

Ackerly, D. D., and F. A. Bazzaz. 1995. Plant growth and reproduction along $\mathrm{CO}_{2}$ gradients: non-linear responses and implications for community change. Global Change Biology 1:199-207.

Andrews, J. A., K. G. Harrison, R. Matamala, and W. H. Schlesinger. 1999. Separation of root respiration from total soil respiration using carbon-13 labeling during Free-Air Carbon Dioxide Enrichment (FACE). Soil Science Society of America 63:1429-1435.

Barford, C. C., S. C. Wofsy, M. L. Goulden, J. W. Munger, E. H. Pyle, S. P. Urbanski, L. Hutyra, S. R. Saleska, D. Fitzjarrald, and K. Moore. 2001. Factors controlling long- and short-term sequestration of atmospheric $\mathrm{CO}_{2}$ in a mid-latitude forest. Science 294:1688-1691.

Bazzaz, F. A. 1996. Plants in changing environments: linking physiological, population, and community ecology. Cambridge University Press, New York, New York, USA.

Bazzaz, F. A., J. S. Coleman, and S. R. Morse. 1990. Growth responses of seven major co-occurring tree species of the northeastern United States to elevated $\mathrm{CO}_{2}$. Canadian Journal of Forest Research 20:1479-1484.

Bazzaz, F. A., and K. D. M. McConnaughay. 1992. Plant-plant interactions in elevated $\mathrm{CO}_{2}$ environments. Australian Journal of Botany 40:547-563.

Bazzaz, F. A., and S. L. Miao. 1993. Successional status, seed size, and responses of tree seedlings to $\mathrm{CO}_{2}$, light, and nutrients. Ecology 74:104-112.

Bazzaz, F. A., and S. T. A. Pickett. 1980. Physiological ecology of tropical succession: a comparative review. Annual Review of Ecology and Systematics 11:287-310.

Beedlow, P. A., D. T. Tingey, D. L. Phillips, W. E. Hogsett, and D. M. Olszyk. 2004. Rising atmospheric $\mathrm{CO}_{2}$ and carbon sequestration in forests. Frontiers in Ecology and the Environment 2:315-322.

Belote, R. T., J. F. Weltzin, and R. J. Norby. 2004. Response of an understory plant community to elevated $\left[\mathrm{CO}_{2}\right]$ depends on differential responses of dominant invasive species and is mediated by soil water availability. New Phytologist 161:827835.

Bergh, J., M. Freeman, B. D. Sigurdsson, S. Kellomäki, K. Laitinen, S. Niinistö, H. Peltola, and S. Linder. 2003.
Modeling the short-term effects of climate change on the productivity of selected tree species in Nordic countries. Forest Ecology and Management 183:327-340.

Bolker, B. M., S. W. Pacala, F. A. Bazzaz, C. D. Canham, and S. A. Levin. 1995. Species diversity and ecosystem response to carbon dioxide fertilization: conclusions from a temperate forest model. Global Change Biology 1:373-381.

Brown, K. R., and K. O. Higginbotham. 1986. Effects of carbon dioxide enrichment and nitrogen supply on growth of boreal trees seedlings. Tree Physiology 2:223-232.

Burns, R. M., and B. H. Honkala. 1990. Silvics of North American trees. Volume 2. Hardwoods. U.S. Department of Agriculture, Washington, D.C., USA.

Canham, C. D., A. C. Finzi, S. W. Pacala, and D. H. Burbank. 1994. Causes and consequences of resource heterogeneity in forests: interspecific variation in light transmission by canopy trees. Canadian Journal of Forest Resources 24:337-349.

Cao, M., S. D. Prince, J. Small, and S. J. Goetz. 2004. Remotely sensed interannual variations and trends in terrestrial net primary productivity 1981-2000. Ecosystems 7:233-242.

Caspersen, J. P., S. W. Pacala, J. C. Jenkins, G. C. Hurtt, P. R. Moorcroft, and R. A. Birdsey. 2000. Contributions of landuse history to carbon accumulation in U.S. forests. Science 290:1148-1151.

Chen, K., H. G. Hu, N. Keutgen, M. J. Janssens, and F. Lenz. 1999. Effects of $\mathrm{NaCl}$ salinity and $\mathrm{CO}_{2}$ enrichment on pepino (Solanum muricatum Ait.): leaf photosynthetic properties and gas exchange. Scientia-Horticultae-Amsterdam 81:43-56.

Christensen, N. L., and R. K. Peet. 1981. Secondary forest succession on the North Carolina piedmont. Pages 230-245 in D. C. West, H. H. Shugart, and D. B. Botkin, editors. Forest succession: concepts and applications. SpringerVerlag, New York, New York, USA.

Christensen, N. L., and R. K. Peet. 1984. Convergence during secondary forest succession. Journal of Ecology 72:25-36.

Ciais, P., P. P. Tans, M. Trolier, J. W. C. White, and R. J. Francey. 1995. A large northern hemisphere terrestrial $\mathrm{CO}_{2}$ sink indicated by the ${ }^{13} \mathrm{C} /{ }^{12} \mathrm{C}$ ratio of atmospheric $\mathrm{CO}_{2}$. Science 269:1098-1102.

Clark, J. S., J. Mohan, M. Dietze, and I. Ibanez. 2003. Coexistence: how to identify trophic trade-offs. Ecology 84: $17-31$.

Curtis, P. S., and X. Wang. 1998. A meta-analysis of elevated $\mathrm{CO}_{2}$ effects on woody plant mass, form, and physiology. Oecologia 113:299-313.

Deckmyn, G., B. Muys, J. Garcia Quijano, and R. Ceulemans. 2004. Carbon sequestration following afforestation of agricultural soils: comparing oak/beech forest to shortrotation poplar coppice combining a process and a carbon accounting model. Global Change Biology 10:1482-1491.

Delcourt, H. R., and W. F. Harris. 1980. Carbon budget of the southeastern U.S. biota: analysis of historical change in trend from source to sink. Science 210:321-323.

DeLucia, E. H., R. M. Callaway, and W. H. Schlesinger. 1994. Offsetting changes in biomass allocation and photosynthesis in ponderosa pine (Pinus ponderosa) in response to climate change. Tree Physiology 14:669-677.

DeLucia, E. H., J. G. Hamilton, S. L. Naidu, R. B. Thomas, J. A. Andrews, A. Finzi, M. Lavine, R. Matamala, J. E. Mohan, G. R. Hendrey, and W. H. Schlesinger. 1999. Net carbon storage in an intact forest under experimental $\mathrm{CO}_{2}$ enrichment. Science 284:1177-1179.

Dixon, R. K., S. Brown, R. A. Houghton, A. M. Solomon, M. C. Trexler, and J. Wisniewski. 1994. Carbon pools and flux in global forest ecosystems. Science 263:185-190.

Downs, R. J., and H. Hellmers. 1978. Controlled climate and plant research. World Meteorological Organization Technical Note Number 148. Academic Press, Geneva, Switzerland.

Ehleringer, J., and O. Björkman. 1977. Quantum yields for $\mathrm{CO}_{2}$ uptake in $\mathrm{C}_{3}$ and $\mathrm{C}_{4}$ plants. Plant Physiology 59:86-90. 
Field, C. B., F. S. Chapin, III, P. A. Matson, and H. A. Mooney. 1992. Responses of terrestrial ecosystems to the changing atmosphere: a resource-based approach. Annual Review of Ecology and Systematics 23:201-235.

Finzi, A. C., and C. D. Canham. 2000. Sapling growth in response to light and nitrogen availability in a southern New England forest. Forest Ecology and Management 131: $153-165$.

Finzi, A. C., E. H. DeLucia, and W. H. Schlesinger. 2004. Canopy $\mathrm{N}$ and $\mathrm{P}$ dynamics of a southeastern U.S. pine forest under elevated $\mathrm{CO}_{2}$. Biogeochemistry 69:363-378.

Foster, D. R., G. Motzkin, J. O'Keefe, E. Boose, D. Orwig, J. Fuller, and B. Hall. 2004. The environmental and human history of New England. Pages 43-100 in D. Foster and J. Aber, editors. Forests in time: the environmental consequences of 1,000 years of change in New England. Yale University Press, New Haven, Connecticut, USA.

Gelfand, A. E., and S. K. Ghosh. 1998. Model choice: a minimum posterior predictive loss approach. Biometrika 85:1-11.

Goulden, M. L., J. W. Munger, S. Fan, B. C. Daube, and S. C. Wofsy. 1996. Exchange of carbon dioxide by a deciduous forest: response to interannual climate variability. Science 271:1576-1578.

Harlow, W. M., E. S. Harrar, J. W. Hardin, and F. M White. 1991. Textbook of dendrology. Seventh edition. McGrawHill, New York, New York, USA.

Hättenschwiler, S. 2001. Tree seedling growth in natural deep shade: functional traits related to interspecific variation in response to elevated $\mathrm{CO}_{2}$. Oecologia 129:31-42.

Hättenschwiler, S., and C. Körner. 1996. Effects of elevated $\mathrm{CO}_{2}$ and increased nitrogen deposition on photosynthesis and growth of understory plants in spruce model ecosystems. Oecologia 106:172-180.

Hättenschwiler, S., and C. Körner. 2000. Tree seedlings responses to in situ $\mathrm{CO}_{2}$-enrichment differ among species and depend on understory light availability. Global Change Biology 6:213-226.

Hendrey, G. R., D. S. Ellsworth, K. F. Lewin, and J. Nagy. 1999. A free-air $\mathrm{CO}_{2}$ enrichment system for exposing tall forest vegetation to elevated atmospheric $\mathrm{CO}_{2}$. Global Change Biology 5:293-309.

Hoddinott, J., and R. Scott. 1996. The influence of light quality and carbon dioxide enrichment in the growth and physiology of seedlings of three conifer species. I. Growth responses. Canadian Journal of Botany 74:383-390.

Houghton, R. A. 2003. Why are estimates of the terrestrial carbon balance so different? Global Change Biology 9:500-509.

Hurtt, G. C., S. W. Pacala, P. R. Moorecroft, J. Caspersen, E. Shevliakova, R. A. Houghton, and B. Moore III. 2002. Projecting the future of the U.S. carbon sink. Proceedings of the National Academy of Sciences (USA) 99:1389-1394.

Huynh, H., and L. S. Feldt. 1976. Estimation of the box correction for degrees of freedom from sample data in the randomized block and split plot designs. Journal of Educational Statistics 1:69-82.

Idso, S. B., B. A. Kimball, and S. G. Allen. 1991. $\mathrm{CO}_{2}$ enrichment of sour orange trees: two and a half years into a longterm experiment. Plant, Cell and Environment 14:351-353.

Imhoff, M. L., L. Bounoua, T. H. Ricketts, C. Loucks, R. Harriss, and W. T. Lawrence. 2004. Global patterns in human consumption of net primary production. Nature 429: 870-873.

Kartesz, J. T. 1994. A synonymized checklist of the vascular flora of the United States, Canada, and Greenland. Timber Press, Portland, Oregon, USA.

Keever, C. 1950. Causes of succession on old fields of the piedmont, North Carolina. Ecological Monographs 20: 231-250.

Kerstiens, G. 1998. Shade-tolerance as a predictor of responses to elevated $\mathrm{CO}_{2}$ in trees. Physiologia Plantaum 102:472-480.
Kerstiens, G. 2001. Meta-analysis of the interaction between shade-tolerance, light environment and growth response of woody species to elevated $\mathrm{CO}_{2}$. Acta Oecologia 22:61-69.

Khurana, E., and J. S. Singh. 2004. Response of five dry tropical tree seedlings to elevated $\mathrm{CO}_{2}$ : impact of seed size and successional status. New Forests 27:139-157.

Kinney, K. K., and R. L. Lindroth. 1997. Responses of three deciduous tree species to atmospheric $\mathrm{CO}_{2}$ and soil $\mathrm{NO}_{3}{ }^{-}$ availability. Canadian Journal of Forest Resources 27:1-10.

Kirschbaum, M. 2003. Can trees buy time? An assessment of the role of vegetation sinks as part of the global carbon cycle. Climatic Change 58:47-71.

Kobe, R. K., and K. D. Coates. 1997. Models of sapling mortality as a function of growth to characterize interspecific variation in shade tolerance of eight tree species of northwestern British Columbia. Canadian Journal of Forest Resources 27:227-236.

Kobe, R. K., S. W. Pacala, J. A. Silander, Jr., and C. D. Canham. 1995. Juvenile tree survivorship as a component of shade tolerance. Ecological Applications 5:517-532.

Kubiske, M. E., and K. S. Pregitzer. 1996. Effects of elevated $\mathrm{CO}_{2}$ and light availability on the photosynthetic light response of trees of contrasting shade tolerance. Tree Physiology 16:351-358.

Kubiske, M. E., and K. S. Pregitzer. 1997. Ecophysiological responses to simulated canopy gaps of two tree species of contrasting shade tolerance in elevated $\mathrm{CO}_{2}$. Functional Ecology 11:24-32.

LaDeau, S. L., and J. S. Clark. 2001. Rising $\mathrm{CO}_{2}$ levels and the fecundity of forest trees. Science 292:95-98.

Landis, R. M., and D. R. Peart. 2005. Early performance predicts canopy attainment across life histories in subalpine forest trees. Ecology 86:63-72.

Laurance, W. F., A. A. Oliveira, S. G. Laurance, R. Condit, H. E. M. Nascimento, A. C. Sanchez-Thorin, T. E. Lovejoy, A. Andrade, S. D'Angelo, and C. Dick. 2004. Pervasive alteration of tree communities in undisturbed Amazonian forests. Nature 428:171-175.

Lloyd, J., and G. D. Farquhar. 1996. Responses to elevated atmospheric $\mathrm{CO}_{2}$ concentrations and their interaction with soil nutrient status. I. General principles and forest ecosystems. Functional Ecology 10:4-32.

Lorimer, C. G. 1983. A test of the accuracy of shade-tolerance classifications based on physiognomic and reproductive traits. Canadian Journal of Botany 61:1595-1598.

Martin, W. H., S. G. Boyce, and A. C. Echternacht. 1993. Biodiversity of the southeastern United States: upland terrestrial communities. John Wiley and Sons, New York, New York, USA.

Mohan, J. E. 2002. Atmospheric carbon dioxide effects on temperate forests: implications for plant evolution, forest succession, and nutrient turnover. Dissertation. Department of Biology, Duke University, Durham, North Carolina, USA.

Mohan, J. E., J. S. Clark, and W. H. Schlesinger. 2004. Genetic variation in germination, growth and survivorship of red maple in response to subambient through elevated atmospheric $\mathrm{CO}_{2}$. Global Change Biology 10:233-247.

Niklaus, P. A., and Ch. Körner. 2004. Synthesis of a six-year study of calcareous grassland responses to in situ $\mathrm{CO}_{2}$ enrichment. Ecological Monographs 74:491-511.

Nowak, R. S., D. S. Ellsworth, and S. D. Smith. 2004. Functional responses of plants to elevated atmospheric $\mathrm{CO}_{2}-$ do photosynthetic and productivity data from FACE experiments support early predictions? New Phytologist 162:253-280.

O'Leary, M. H. 1988. Carbon isotopes in photosynthesis. BioSciences 38:328-336.

Oosting, H. J. 1942. An ecological analysis of the plant communities of Piedmont, North Carolina. American Midland Naturalist 28:1-126. 
Oren, R., D. S. Ellsworth, K. H. Johnsen, N. Phillips, B. E. Ewers, C. Maier, K. V. R. Schafer, H. McCarthy, G. Hendrey, S. G. McNulty, and G. G. Katul. 2001. Soil fertility limits carbon sequestration by forest ecosystems in a $\mathrm{CO}_{2}$-enriched atmosphere. Science 411:469-472.

Pacala, S. W., C. D. Canham, J. Soponara, J. A. Silander, Jr., R. K. Kobe, and E. Ribbens. 1996. Forest models defined by field measurements: estimation, error analysis and dynamics. Ecological Monographs 66:1-43.

Pacala, S. W., et al. 2001. Consistent land- and atmospherebased U.S. carbon sink estimates. Science 292:2316-2320.

Pearson, P. N., and M. R. Palmer. 2000. Atmospheric carbon dioxide concentrations over the past 60 million years. Nature 406:695-699.

Peet, R. K. 1992. Community structure and ecosystem function. Pages 103-151 in D. C. Glenn-Lewin, R. K. Peet, and T. T. Veblen, editors. Plant succession: theory and prediction. Chapman and Hall, London, UK.

Petit, J. R., et al. 1999. Climate and atmospheric history of the past 420,000 years from the Vostok ice core, Antarctica. Nature 399:429-438.

Pickett, S. T. A., and P. S. White. 1985. The ecology of natural disturbance and patch dynamics. Academic Press, New York, New York, USA.

Polley, H. W., H. B. Johnson, and J. D. Derner. 2003. Increasing $\mathrm{CO}_{2}$ from subambient to superambient concentrations alters species composition and increases aboveground biomass in $\mathrm{a}_{3} / \mathrm{C}_{4}$ grassland. New Phytologist 160: 319-327.

Poorter, H. 1993. Interspecific variation in the growth responses of plants to an elevated ambient $\mathrm{CO}_{2}$ concentration. Vegetatio 104/105:77-97.

Poorter, H. 1998. Do slow-growing species and nutrientstressed plants respond relatively strongly to elevated $\mathrm{CO}_{2}$ ? Global Change Biology 4:693-697.

Potvin, C., and L. Vasseur. 1997. Long-term $\mathrm{CO}_{2}$ enrichment of a pasture community: species richness, dominance, and succession. Ecology 78:666-677.

Prentice, I. C., G. D. Farquhar, M. J. R. Fasham, M. L. Goulden, M. Heimann, V. J. Jaramillo, H. S. Kheshgi, C. LeQuéré, R. J. Scholes, and D. W. R. Wallace. 2001. The carbon cycle and atmospheric carbon dioxide. Pages 204-237 in J. T. Houghton, Y. Ding, D. J. Griggs, M. Noguer, P. J. van der Linden, X. Dai, K. Maskell, and C. A. Johnson, editors. Climate change 2001: the scientific basis. Contribution of Working Group I to the Third Assessment Report of the Intergovernmental Panel on Climate Change. Cambridge University Press, Cambridge, UK.

Reid, C. D., and B. R. Strain. 1994. Effects of $\mathrm{CO}_{2}$ enrichment on whole-plant carbon budget of seedlings of Fagus grandifolia and Acer saccharum in low irradiance. Oecologia 98:31-39.

Rich, P. M. 1989. A manual for analysis of hemispherical canopy photography. Publication LA-11733-M. Los Alamos National Laboratory, Los Alamos, New Mexico, USA.

Ryan, M. G., D. Binkley, and J. H. Fownes. 1997. Age-related decline in forest productivity: pattern and process. Advances in Ecological Research 27:214-262.

Ryan, M. G., D. Binkley, J. H. Fownes, C. P. Giardina, and R. S. Senock. 2004. An experimental test of the causes of forest growth decline with stand age. Ecological Monographs $74: 393-414$.

SAS. 1990. User's Guide: statistics. Version 6. Fourth edition. SAS Institute, Cary, North Carolina, USA.

Schlesinger, W. H. 1997. Biogeochemistry: an analysis of global change. Second edition. Academic press, San Diego, California, USA.

Shaver, G. R., J. Canadell, F. S. Chapin, III, J. Gurevitch, J. Harte, G. Henry, P. Ineson, S. Jonasson, J. Melillo, L. Pitelka, and L. Rustad. 2000. Global warming and terrestrial ecosystems: a conceptual framework for analysis. BioScience 50:871-882.

Sokal, R. R., and F. J. Rohlf. 1995. Biometry: the principles and practice of statistics in biological research. W. $\mathrm{H}$. Freeman, New York, New York, USA.

Vitousek, P. M., H. A. Mooney, J. Lubchenco, and J. M. Melillo. 1997. Human domination of earth's ecosystems. Science 277:494-499.

Wang, X., P. S. Curtis, K. S. Pregitzer, and D. R. Zak. 2000. Genotypic variation in physiological and growth responses of Populus tremuloides to elevated atmospheric $\mathrm{CO}_{2}$ concentrations. Tree Physiology 20:1019-1028.

Wardle, D. A., L. R. Walker, and R. D. Bardett. 2004. Ecosystem properties and forest decline in contrasting longterm chronosequences. Science 305:509-513.

Wayne, P. M., and F. A. Bazzaz. 1997. Light acquisition and growth by competing individuals in $\mathrm{CO}_{2}$ enriched atmospheres: consequences for size structure in regenerating birch stands. Journal of Ecology 85:29-42.

Wyckoff, P. H., and J. S. Clark. 2002. The relationship between growth and mortality for seven co-occurring tree species in the southern Appalachian Mountains. Journal of Ecology 90: 604-615.

\section{APPENDIX A}

Mass balance equation calculating the $\mathrm{CO}_{2}$ concentration in the understory of elevated plots at the Duke Forest FACE experiment (Ecological Archives A017-044-A1).

\section{APPENDIX B}

Allometric equations developed for species of the FACE site for aboveground biomass (Ecological Archives A017-044-A2).

\section{APPENDIX C}

Hierarchical Bayesian analysis of plant growth at variable light levels at ambient and elevated atmospheric $\mathrm{CO}_{2}$ at the Duke University FACE experiment (Ecological Archives A017-044-A3). 